Investigating the environmental effect of

globalization: Insights from selected industrialized countries

Olufemi Adewale Aluko, Eric Evans Osei Opoku, Muazu Ibrahim

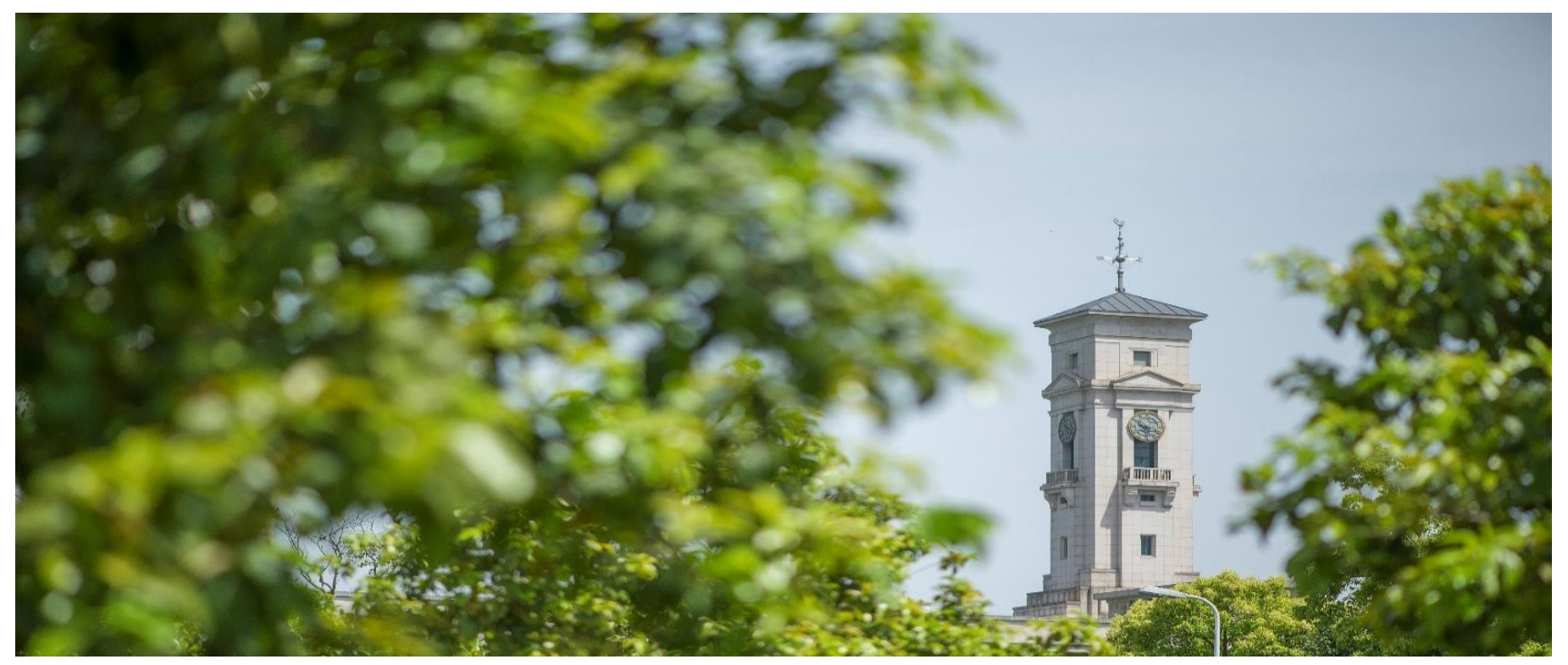


University of Nottingham Ningbo China, 199 Taikang East Road, Ningbo, 315100, Zhejiang, China.

First published 2021

This work is made available under the terms of the Creative Commons Attribution 4.0 International License:

http://creativecommons.org/licenses/by/4.0

The work is licenced to the University of Nottingham Ningbo China under the Global University Publication Licence:

https://www.nottingham.edu.cn/en/library/documents/research/global -university-publications-licence-2.0.pdf 


\title{
Investigating the environmental effect of globalization: Insights from selected industrialized countries
}

\author{
${ }^{\mathrm{a}}$ Olufemi Adewale Aluko* $\quad{ }^{\mathrm{b}}$ Eric Evans Osei Opoku $\quad{ }^{\mathrm{c}}$ Muazu Ibrahim \\ a Department of Finance, University of Ilorin, Kwara State, Nigeria. \\ olufemiadewale6@gmail.com \\ ${ }^{b}$ Nottingham University Business School China, University of Nottingham Ningbo China \\ eric-evans-osei.opoku@nottingham.edu.cn \\ c Department of Banking and Finance, School of Business and Law, \\ University for Development Studies, Post Office Box UPW 36, Wa, Upper West region, Ghana \\ imuazu@uds.edu.gh
}

*Corresponding Author Email: olufemiadewale6@gmail.com

\section{Highlights}

- This study investigates the effect of globalization on environmental degradation.

- This study employs the augmented mean group estimator.

- Overall and economic globalization reduce environmental degradation.

- De facto economic globalization mitigates environmental degradation.

- De jure overall, economic and social globalization limit environmental degradation.

\begin{abstract}
Despite the burgeoning literature on the globalization-environmental degradation nexus, this area of empirical interest is still riddled with ambiguity. Thus, based on an extended Stochastic Impacts by Regression on Population, Affluence and Technology (STIRPAT) model, we re-investigate the effect of globalization on environmental degradation for 27 selected industrialized countries over the period 1991-2016. More specifically, we shed light into how overall globalization and its various components - economic, social and political globalization - affect environmental degradation. We advance existing literature by considering a measurement approach which disaggregates overall, economic, social and political globalization into their de facto and de jure aspects. Using the augmented mean group estimator, we find that overall and economic globalization reduce environmental degradation while social and political globalization do not exert any significant effect on globalization. With respect to the de facto and de jure aspects, we observe that, while only de facto economic globalization mitigates environmental degradation, de jure overall, economic and social globalization also dampen environmental degradation. We provide some policy implications in the end.
\end{abstract}

Keywords: Globalization; environmental degradation; ecological footprint; STIRPAT model 


\section{Introduction}

The climate is changing largely as a result of human activities such as agriculture, construction, fossil fuel burning, solid waste generation, mining etc. These activities are causing harm not only to human life but also to the environment because they emit anthropogenic greenhouse gases (GHG). Human activities are inevitable because they are necessary to achieve economic growth and they in turn ultimately cause damage to the environment (Alagidede, Adu and Frimpong, 2016). Since the industrial revolution, anthropogenic GHG emissions have risen considerably largely as a result of economic and population growth.

The continuous increase in anthropogenic GHG emissions around the world and the attendant environmental problems have raised concerns among countries (Dong, Dong and Dong, 2019; (Khan, Sharif, Golpîra and Kumar, 2019). As a result, many countries have engaged in collaborative efforts which have led to the establishment of international treaties such as the United Nations Framework Convention on Climate Change (UNFCCC), Kyoto Protocol and the Paris Agreement. These treaties emphasize the need to reduce the atmospheric concentration of anthropogenic GHG emissions in order to safeguard the global ecosystem from climate change impacts (such as rising global temperatures and sea levels, floods and drought, and wildfires etc.). For instance, Ritchie and Roser (2020) note that global average temperatures have risen between $1^{\circ} \mathrm{C}$ and $1.2^{\circ} \mathrm{C}$ since the pre-industrial era (period between 1750 and 1850). Similarly, the global average sea level has increased about $21-24 \mathrm{~cm}$ since 1880 (Lindsey, 2020). The Intergovernmental Panel on Climate Change predicts a rise between $1.8^{\circ} \mathrm{C}$ and $5.8^{\circ} \mathrm{C}$ for global average temperature and $9 \mathrm{~cm}$ and $88 \mathrm{~cm}$ for global average sea level during the $22^{\text {nd }}$ century (Haines \& Patz, 2004). Against this backdrop, empirical studies on the factors responsible for environmental degradation have taken center-stage at global discussions. This is because finding innovative ways of reducing climate change impacts is first conditioned on the determination of the precise factors influencing environmental degradation.

The pivotal paper of Grossman and Krueger (1991) offers a groundbreaking insight into how income is associated with environmental degradation. It led to the development of the environmental Kuznets curve (EKC) hypothesis which argues that, at the early stages of development, a rise in income level results in environmental degradation. However, when the income level rises to a certain point, further increase in income lowers environmental degradation. This hypothesis though not conclusive is validated by many empirical studies (Acheampong, Adams and Boateng, 2019; Rafindadi and Usman, 2019). Following the emergence of the EKC hypothesis, an area of research discourse that has been brought to the limelight is the effect of globalization on environmental degradation.

The advocates of globalization are of the opinion that higher levels of globalization lower environmental degradation. Globalization reduces environmental degradation because it encourages stringent environmental regulations on firms (Christmann and Taylor, 2001). The critics of globalization claim that globalization degrades the environment. Globalization damages the environment because it causes rapid depletion of natural resources (Wijen and Van Tulder, 2011). As a result of expansion in production activities which often accompanies further globalization, the environment is likely to be faced with more harm. This is because increase in the demand for energy is often associated with production expansion. Shahbaz, Mallick, Mahalik and Loganathan (2015) note that globalization encourages trade activities which resultantly reduce the performance of the environment when the production process of domestic goods and services 
directly or indirectly requires energy. Trade liberalization facilitated by globalization increases the use of energy (Cole, 2006), which in turn results in lesser environmental quality.

Extant studies have appraised into the environmental effects of overall, economic, social and political globalization (for example, Destek, 2020; Phong, 2019; Shahbaz, Suki, Sharif, Afshan and Suki, 2020; Xu, Baloch, Meng, Zhang and Mahmood, 2018). However, these studies do not distinguish between the de facto and de jure aspects of overall, economic, social and political globalization. This distinction is particularly important as it may potentially exert different effects. While the de facto aspect of globalization represents the actual international flows and activities, the de jure aspect of globalization measures measures policies and conditions that, in principle, enable, facilitate and foster flows and activities (Gygli, Haelg, Potrafke and Sturm, 2019). In this essence, while the de jure aspect can be viewed as an intention variable mirroring an intent to globalize, the de facto aspect of globalization is a resultant variable measuring the actual extent of globalization. This approach allows us to determine the differential impact of these aspects of overall, economic, social and political globalization on environmental degradation. Martens, Caselli, De Lombaerde, Figge and Scholte (2015) strongly support the distinction between de facto and de jure measures of globalization. Designing and implementation of de facto and de jure policies do not follow similar pattern. For instance, unlike de facto policies, de jure policies are prone to enforcement issues (Baltagi, Demetriades and Law, 2009). Kose, Prasad, Rogoff and Wei (2009) argue that policy, particularly de jure policy, can appear to be strict on paper, but has no effect in reality. By distinguishing between the de facto and de jure aspects, we are able to reveal which aspect is more influential on environmental degradation. Through this approach, we contribute novel evidence to the existing body of literature.

The remaining paper is structured as follows. Section 2 reviews the literature while Section 3 presents the methodology which describes the data and empirical strategy. Section 4 discusses the findings of the study. We provide the conclusion and policy implications in Section 5 and Section 6 , respectively.

\section{Literature review}

So far, the existing literature have identified scale effect, technique effect and composition effect as possible environmental effects of globalization (Shahbaz, Mahalik, Shahzad and Hammoudeh, 2019; Tsurumi and Managi, 2010). The scale effect exists when globalization inhibits environmental quality due to its stimulating role in economic activity which leads to the use of more energy. Globalization tends to induce FDI and international trade activities which serve as channels through which clean and energy-efficient technologies may be transferred into countries. By using clean and energy-efficient technologies, environmental quality is enhanced (Khan, Zhang, Kumar, Zavadskas and Streimikiene, 2020; Yu, Tianshan and Khan, 2020). This phenomenon is referred to as the technique effect. The composition effect arises when globalization via trade alters the industrial structure by changing the capital-labour ratio, which may either have a positive or negative effect on the environment (Cole, 2006; Shahbaz, Mahalik, Shahzad and Hammoudeh, 2019).

Due to the implications of globalization for the environment, empirical literature on the effect of globalization on environmental degradation has been burgeoning. Most studies investigated this 
effect within the framework of the EKC model. However, Harbaugh, Levinson and Wilson (2002) criticize the EKC model for being deterministic. Specifically, they argue that the prediction of EKC model may not be true due to the sensitivity of the income-environment relationship to sample selection and empirical specifications. Thus, some studies disregard the application of the EKC model; they use either the Stochastic Impacts by Regression on Population, Affluence and Technology (STIRPAT) model or an ad-hoc modelling approach. A group of empirical studies argues that increasing globalization would reduce environmental degradation (Baloch, Ozturk, Bekun and Khan, 2016; Saud, Chen and Haseeb, 2020; Zafar, Saud and Hou, 2019). This argument is backed by the negative effect of globalization on environmental degradation. Another group of studies raises doubt on the mitigating role of globalization in environmental degradation. On the contrary, this group argues that higher levels of globalization would cause further degradation of the environment as a result of the positive effect of globalization on environmental degradation (Bu, Lin and Zhang, 2016; Destek, 2020; Le and Ozturk, 2020; Phong, 2019; Sabir and Gorus, 2019).

Globalization is a multidimensional concept which includes economic, social and political dimensions (Dreher, 2006; Gygli, Haelg, Potrafke and Sturm, 2019). Thus, a number of studies have considered the effect of globalization on environmental degradation from a dimensional perspective. For instance, Xu, Baloch, Meng, Zhang and Mahmood (2018) show that, while social globalization does not have any impact in the short and long run, economic globalization degrades the environment in both runs. They also show that political globalization causes environmental degradation in the short run only. Khan and Ullah (2019) find that economic, social and political globalization degrade the environment in the short and long run. Destek (2020) documents that, while political globalization has a favourable effect on the environment, social globalization has no significant effect, and environment degradation increases with rise in economic globalization. $\mathrm{Bu}$, Lin and Zhang (2016) demonstrate that further degradation of the environment is associated with increase in economic, social and political globalization. Lv and Xu (2018) examine the environmental effect of economic globalization only and show that economic globalization reduces environmental degradation. Similarly, Ulucak, İlkay, Özcan and Gedikli (2020) look into how financial globalization (sub-dimension of economic globalization) influences environmental degradation. They find that financial globalization mitigates environmental degradation.

A seminal study by Shahbaz, Mahalik, Shahzad and Hammoudeh (2019) examines the relationship between globalization and the environment based on the philosophy of the EKC hypothesis. The authors use a sample consisting of 87 countries over the period 1970-2012 and the crosscorrelation dynamic test. They find an inverted U-shaped relationship in 16 countries, indicating that globalization initially degrades the environment in these countries but it eventually improves the environment after the globalization threshold level is exceeded [see Balsalobre-Lorente, Driha, Shahbaz and Sinha (2020) for supporting evidence]. They also find a U-shaped relationship in 7 countries, suggesting that globalization reduces environmental degradation initially, but it contributes to environmental degradation in the future. These findings offer evidence to argue that globalization has a nonlinear effect on environmental degradation. Shahbaz, Shahzad and Mahalik (2018) also support this argument. They find that the effect of globalization on environmental degradation in Japan is asymmetric based on a threshold nonlinear Autoregressive Distributed Lag 
(ARDL) model, with the negative shocks of globalization degrading the environment more than the positive shocks.

Table 1 provides a summary of empirical studies offering evidence on the effect of globalization on environmental degradation, with this effect still ambiguous. While there have been notable efforts to empirically examine how globalization influence environmental degradation, how the different aspects of overall, economic, social and political globalization - de facto and de jure influence environmental degradation is yet to be documented. To the best of our knowledge, we could not find any study that has made a distinction between the de facto and de jure aspects of globalization. Distinguishing between the de facto and de jure aspects of globalization is very crucial in providing a robust evidence on the environmental effect of globalization. In the growth literature, Feld and Voigt (2003) and Voigt, Gutmann and Feld (2015) stress on the importance of differentiating between de facto and de jure aspects of institutions. Quinn, Schindler and Toyoda (2011) also show that distinguishing between de facto and de jure financial openness produce systematically different findings. Given the inconclusive findings coupled with the dearth of studies examining the effect of globalization in addition to its different dimensions and aspects, this study fills the gaps in the literature by investigating these nuances.

\section{[Table 1 here]}

\section{Methodology}

\subsection{Model}

The STIRPAT model by Dietz and Rosa (1994) has been widely used to assess environmental impact of some economic variables (see, for example, Aluko and Obalade, 2020; Li and Lin, 2015; $\mathrm{Lv}$ and $\mathrm{Xu}, 2018$ ). The STIRPAT model improves on the IPAT mathematical identity equation. This identity explores the impact of population, affluence and technology on the environment. Li and Lin (2015) argue that the IPAT model does not allow test for hypothesis. Noting the limitations of the IPAT identity equation, Dietz and Rosa (1994) transform it into a stochastic equation in order to allow for other potential factors that can determine environmental degradation to be accounted for. The basic STIRPAT model is a nonlinear model expressed as:

$I_{i t}=a P_{i t}^{\delta} A_{i t}^{\alpha} T_{i t}^{\beta} \varepsilon_{i t}$

where $I_{i t}$ represents environmental degradation, $P_{i t}, A_{i t}$ and $T_{i t}$ respectively denote population, affluence and technology; $\varepsilon_{i t}$ is the stochastic term; $i$ is the country index while $t$ is the time index.

The STIRPAT model in Equation (1) is linearized by transforming it into its logarithmic form presented as:

$\ln I_{i t}=\ln a+\delta \ln P_{i t}+\alpha \ln A_{i t}+\beta \ln T_{i t}+\varepsilon_{i t}$

where $\ln$ stands for logarithm and $\delta, \alpha$ and $\beta$ respectively represent population, affluence and technology elasticities/coefficients.

To assess the environmental effect of globalization, Equation (2) is augmented with the proxy of globalization $(X)$ : 
$\ln E D_{i t}=\ln a+\delta \ln P_{i t}+\alpha \ln A_{i t}+\beta \ln T_{i t}+\gamma \ln X_{i t}+\varepsilon_{i t}$

where $E D_{i t}$ denotes environmental degradation and $X_{i t}$ represents a vector of overall globalization (OG) and its main components - economic globalization (EG), social globalization (SG) and political globalization (PG).

\subsection{Data}

We rely on a sample of 27 industrialized countries over the 1991-2016 period, which is constructed on the basis of data availability. For countries included in the panel dataset, see Table A.1 in the Appendix. The dependent variable is environmental degradation. In lieu of $\mathrm{CO}_{2}$ emissions, we use ecological footprint (in per capita terms) to proxy environmental degradation. Relying on ecological footprint to capture the level of environmental degradation is consistent with some recent studies (see Sabir and Gorus, 2019; Saud, Chen and Haseeb, 2020; Ulucak, İlkay, Özcan and Gedikli, 2020). Most studies on the environmental effect of globalization have been based on pollutant emissions such as $\mathrm{CO}_{2}$ emissions (see, for instance, Wang, Rasool, Asghar and Wang, 2019; Zafar, Saud and Hou, 2019; Opoku and Boachie, 2020). While pollutant emissions reflect only gases emitted from anthropogenic human activities, ecological footprint measures the impact of anthropogenic human activities on the environment. Ecological footprint shows the extent to which the demands of humans on the biosphere exceed the capacity of the biosphere to meet to those demands (Wackernagel and Kitzes, 2008). Higher values of ecological footprint indicate higher levels of environmental degradation.

Globalization is the main independent variable in this study. Similar to recent studies (Shujah-urRahman, Chen, Saud, Bano and Haseeb, 2019; Wang, Rasool, Asghar and Wang, 2019), we rely on the KOF indices in the dataset developed by Gygli, Haelg, Potrafke and Sturm (2019) for measures of overall, economic, social and political globalization. These indices are on a scale of $0-100$, with 0 being the lowest and 100 being the highest. Gygli, Haelg, Potrafke and Sturm's (2019) dataset is an extension of the work of Dreher (2006). A unique feature of this dataset is that it unbundles globalization and its various dimensions into their de facto and de jure aspects. This dataset can be accessed online from http://www.kof.ethz.ch/globalisation/. While the de facto globalization measures actual flows and activities, de jure globalization measures policies, resources, conditions and institutions that, in principle, enable or facilitate actual flows and activities (Gygli, Haelg, Potrafke and Sturm, 2019: 544).

The other independent variables are population, affluence and technology. Population is directly associated with energy consumption which is a significant contributor to environmental degradation (Martínez-Zarzoso, Bengochea-Morancho and Morales-Lage, 2007; Khan, Yu, Golpîra, Sharif and Mardani, 2020). Population is measured by the total population size of a country, similar to Li and Lin (2015) and Opoku and Boachie (2020). Increase in affluence often results in higher energy consumption which consequently leads to further degradation of the environment. In congruence with most studies (for example, Aluko and Obalade, 2020; Lv and $\mathrm{Xu}, 2018$ ), we measure affluence with GDP per capita. The effect of technology on environmental degradation is mixed. Frankel and Rose (2002) argue that increase in technology can lower environmental degradation because environmental-friendly machineries and equipment may 
become more accessible with advancements in technology. However, Jevon's (1866) paradox argue that technological advancements may result in further deterioration of the environment due to the rise in energy demand they may cause. There are varied ways to measure technology in empirical studies. To proxy technology, we settle for a measure of innovation in line with Nguyen, Pham and Tram (2020). Thus, technology is proxied by the share of gross domestic spending on research and development $(\mathrm{R} \& D)$ in GDP.

Table A.2 in the Appendix presents the measurement of data used in this study and their respective sources. The descriptive statistics of the data (in raw form) used in this study are presented in Table A.3 in the Appendix. On the average, there is high globalization in our sampled countries along all the measures. This is the case as the score of any of the measures exceeds 50. This implies that the industrialized countries are highly globalized. The results further indicate that as the sampled countries are globalized highest politically, they are least economically on the average. In all the measures, de jure globalization presents the highest globalization indices on the average. This indicates that countries are more globalized in the policies and conditions that facilitate the flow of activities than the actual flow of activities.

\subsection{Empirical strategy}

The empirical strategy adopted in this study is discussed as follows:

Step 1: A major concern in cross-country estimations is the presence of cross-sectional dependence (CD) in panel series and model residuals, which may cause spurious results. Thus, we check for cross-sectional dependence (CD) in the variables (panel series) and model residuals. This test is particularly important due to the high level of integration which exists among the industrialized countries. Pesaran (2004) and Pesaran, Ullah and Yamagata (2008) CD test are used to test for $\mathrm{CD}$ in the variables and panel model residuals, respectively. The former and latter respectively test the null hypothesis that the variables and model residuals are not cross-sectionally dependent.

Step 2: We test for the presence of unit root in the panel series. To do this, we use the Pesaran (2007) CIPS unit root test which is a second-generation panel unit root test which accounts for heterogeneity and assumes cross-sectional dependence. This test hypothesizes that the variable is not stationary.

Step 3: We test the homogeneity of the slope coefficients. If the slope coefficients are truly heterogeneous but incorrectly assumed to homogenous, Pesaran and Smith (1995) argue that biased results may be produced. We rely on the Pesaran and Yamagata (2008) standard $(\tilde{\Delta})$ and bias-adjusted delta $\left(\tilde{\Delta}_{a d j}\right)$ tests for slope homogeneity which determine whether slope coefficients are homogeneous or heterogeneous under the null hypothesis of homogeneous slope coefficients.

Step 4: Finally, the Augmented Mean Group (AMG) estimator is utilized to estimate the econometric model. Building on the Mean Group (MG) estimator developed by Pesaran and Smith (1995), Eberhardt and Bond (2009) introduce the AMG estimator. Just like the MG estimator, the AMG estimator accounts for slope heterogeneity and it is robust to cross-sectional dependence. The estimator is robust to nonstationary variables, whether they are cointegrated or not. Thus, the 
test for cointegration is not a prerequisite before applying the AMG estimator (see, for instance, Eberhardt, Helmers and Strauss, 2013; Hernandez-Vega, 2019). The AMG estimator is implemented in a two-stage process. First, a pooled differenced ordinary least squares (OLS) model with time dummies is estimated to obtain the common dynamic process. The AMG estimator deals with the issue of cross-sectional dependence through the common dynamic process. Eberhardt and Bond (2009) describe the common dynamic process as "the levelsequivalent mean evolvement of unobserved common factors across all countries". The common dynamic process is either: (i) included in the model as an additional regressor or (ii) subtracted from the dependent variable. The former approach is followed in our estimations. Second, the AMG coefficients are then computed by averaging the coefficients derived from the $N$ crosscountry regressions.

\section{Results and Discussion}

\subsection{Cross-sectional dependence tests results}

The results of the CD test for the variables and models are respectively reported in Table A.4 and Table A.5 (see Appendix). Pesaran (2004) CD test rejects the null hypothesis for all variables at $1 \%$ significance level, indicating that all the variables are cross-sectionally dependent. Also, at the $1 \%$ significance level, Pesaran, Ullah and Yamagata (2008) CD test rejects the null hypothesis of cross-sectionally dependent residuals for all models used in this study and this suggests that there is no cross-sectional independence in the model residuals. These results suggest strong evidence of the cross-sectional dependence problem. The presence of cross-sectional dependence in the variables and model residuals may lead to spurious estimations. This makes the use of the AMG estimator appropriate as it is able to handle cross-sectional dependence.

\subsection{Panel unit root test results}

As we observed that all the variables exhibit cross-sectional dependence, it is therefore imperative to use a panel unit root test which allows for cross-sectional dependence in the variables. Therefore, the decision to use the Pesaran (2007) CIPS unit root test is appropriate because it is based on the assumption of cross-sectional dependence. It is worthy to mention we perform the panel unit root test to check for the order of integration of the variables. It is important to avoid variables with integration in the second order because their presence in the model may result in biased estimates. The results of the Pesaran (2007) CIPS unit root test are shown in Table A.6 (see Appendix). We deduce that none of the variables require differencing at second order to achieve stationarity. Thus, none of the variables is integrated in the second order.

\subsection{Slope homogeneity tests results}

Table A.7 (see Appendix) reports the results of the Pesaran and Yamagata (2008) standard $(\tilde{\Delta})$ and bias-adjusted delta $\left(\tilde{\Delta}_{a d j}\right)$ tests for slope homogeneity. The results indicate that both tests reject the null hypothesis that the slope coefficients are homogeneous at $1 \%$ significance level for all models and this implies that that the models are indeed heterogeneous in nature. Thus, the application of the AMG estimator in this study is ideal because it accounts for slope heterogeneity.

\subsection{Estimation results}

After checking the properties of the data as given above, and considering that our choice of estimator, the AMG, remains robust in the face of all the properties found in Tables A.4-A.7, we proceed with the estimations. The estimation results are reported in Tables 2-5, distinguished by the measures of globalization; overall globalization index (Table 2), economic globalization (Table 
3), social globalization (Table 4) and political globalization (Table 5). In all the estimates, we report the overall measure, in addition to the de facto and de jure measures, and for each we include and exclude trend.

Commencing with the overall globalization index (OG), the results indicate negative and statistically significant (1\% and 5\%) coefficients (see Table 2). The results hold for both trend and without trend. Specifically, the results show that $1 \%$ rise in overall globalization is associated with between $0.544 \%$ to $0.814 \%$ reduction in environmental degradation, hence improvement in environmental performance.

\section{[Table 2 here]}

The results of the study support the strand of the literature that argues that globalization does not harm the environment but rather improves it. This finding agrees with the technique effect of globalization (see Zaidi, Zafar, Shahbaz and Hou, 2019). The literature upholding that globalization improves environmental performance generally argues that globalization stimulates FDI and trade (Zafar, Saud and Hou, 2019). Foreign investors are noted to possess superior technologies and as a result FDI comes with more efficient ways of production and energyefficient technologies. These better ways of doing business position foreign investors to be competitive and enable them to survive and thrive in host countries. With increase in global competition, firms improve on the standards of their products so they can remain in business. In doing this, they also improve on environmental issues (Zaidi, Zafar, Shahbaz and Hou, 2019). The spill-over effect that maybe associated with FDI, could make efficiency spread even among local firms. Through the efficient technologies that may be associated with FDI, improved environmental quality may come with their activities. Considering also that the countries in our sample are mainly developed countries, FDI inflows to these countries are mainly not exploitative of natural resources (as in the case of Africa) which degrades the environment. Considering the level of development, the countries would be interested in attracting investors with green technology (Khan and Yu, 2020).

Regarding trade, developed countries tend to move their production of "dirty products" to developing countries - a phenomenon referred to as the pollution haven hypothesis - and usually import mainly finished goods into their countries. As a result, degradation that emanate from production is usually exported to other countries. This therefore reduces environmental degradation in these developed countries. Increase in globalization also inspires stringent environmental regulations (Christmann and Taylor, 2001). As a result, countries especially the developed ones enact more and stringent regulations to protect their environments as globalization increases. Citizens (especially of developed countries) also put enormous pressure on their governments to protect the environment. These factors may account for the outcome of this study and it is highly consistent with a number of studies (see for example, Saud, Chen and Haseeb, 2020; Shujah-ur-Rahman, Chen, Saud, Bano and Haseeb, 2019; Zafar, Saud and Hou, 2019). However, this outcome negates Balsalobre-Lorente, Driha, Shahbaz and Sinha (2020), Le and Ozturk (2020), and Sabir and Gorus (2019).

Following Gygli, Haelg, Potrafke and Sturm (2019), we report results for the de facto (Columns 3-4 of Table 2) and de jure (Columns 5-6 of Table 2) measures of overall globalization; whereas 
"de facto globalization measures actual flows and activities, de jure globalization measures policies, resources, conditions and institutions that, in principle, enable or facilitate actual flows and activities" (Gygli, Haelg, Potrafke and Sturm, 2019: 544). Just like Gygli, Haelg, Potrafke and Sturm (2019) and Quinn, Schindler and Toyoda (2011), we find that the impact of the de facto and de jure measures are different. From Table 2, it is revealed that as the de facto overall globalization lacks statistical significance, the de jure globalization is negative and statistically significant at $1 \%$. The results suggest that it is the de jure measure of overall globalization that drives the mitigating effect of overall globalization on environmental degradation. Hence, the policies, resources, conditions and institutions that enhance actual flows and activities of globalization matter more for the environment than actual flows and activities. The industrialized countries relatively have stronger institutions and proffer better conditions than non-industrialized countries. These may account for the stronger effect of de jure globalization.

\section{[Table 3 here]}

Next, we turn to the subdivisions of the overall globalization index. We begin with economic globalization (EG). Economic globalization includes "trade and financial globalization that characterizes long distance flows of goods, capital and services as well as information and perceptions that accompany market exchanges" (Gygli, Haelg, Potrafke and Sturm, 2019: 546). The results indicate that economic globalization has negative and statistically significant coefficients (at 1\% level) for the overall measure (Table 3). Specifically, a 1\% increase in economic globalization is associated with about $0.21 \%-0.48 \%$ reduction in environmental degradation all other things being equal. This finding is in line with $\mathrm{Lv}$ and $\mathrm{Xu}$ (2018), but contradicts Bu, Lin and Zhang (2016) and Destek (2020). Both de facto and de jure dimensions of economic globalization are found to be relevant as they both have negative and statistically significant coefficients (Table 3). Economic globalization increases the flow of goods and exchanges globally and hence stimulates competition among firms and countries. Foreign investors/firms desiring to enter another country and establish business or export must possess superior technologies that will make them competitive. With the move toward sustainability, it is very important in the developed world that these superior technologies also come with environmental improvement.

\section{[Table 4 here]}

Table 4 reports results based on social globalization (SG). Social globalization expresses the spread of ideas, information, images and people (Gygli, Haelg, Potrafke and Sturm, 2019), and interpersonal, informational and cultural globalization are its constituents. The results indicate that the overall measure of social globalization lacks statistical significance even though negative. This finding therefore indicates that overall social globalization is not relevant for environmental performance. This is in tandem with Destek (2020) and Xu, Baloch, Meng, Zhang and Mahmood (2018), but differs from Bu, Lin and Zhang (2016). Similarly, the de facto dimension of social globalization also lacks statistical significance. The de jure dimension is however negative and statistically significant (5\%). This implies that even though the actual activities of social globalization may not affect the environment, the conditions, policies and institutions laid down for this type of globalization do.

In Table 5, the results indicate that the overall measure as well as de facto and de jure measures of political globalization (PG) have statistically insignificant coefficients. This implies that, 
irrespective of the measure, political globalization is found not to be relevant for environmental performance. This finding aligns with Phong (2019), who find that environmental degradation is not influenced by political globalization. However, Destek (2020) and Khan and Ullah (2019) disagree with this finding. Political globalization involves the diffusion of government policies across countries. The fact that the countries in the sample are independent and sovereign, the influence of another country's "political" policies will be very limited. This may account for the outcome of the results.

\section{[Table 5 here]}

Out of the three dimensions of globalization, economic globalization is found to be the most relevant for environmental performance and drives the effect of globalization on environmental degradation. This is the case as economic globalization is most related to the environment due to its component measurements of production, movement of goods, trade and physical exchange. Hence, social and political globalization largely do not have significant effect on the environment.

Turning to the other variables, affluence (proxied by real GDP per capita) consistently has positive and statistically significant coefficients in all the estimated models (see Tables 2-5). The results indicate that depending on the estimation, a $1 \%$ increase in GDP per capita can lead to up to $0.86 \%$ increase in environmental degradation. All other things being equal, an increase in GDP per capita reflects increase in the wealth of the average citizen of a country. With increase in wealth, the demand for goods and services increases. The production of these goods and services puts extra pressure on the environment through increased energy consumption and exploitation of natural resources. As a result, an increase in affluence of a country can deteriorate its environments from increased used of energy and other resources. The outcome of affluence is consistent with a number of studies (see for example, Aluko and Obalade, 2020; Zaidi, Zafar, Shahbaz and Hou, 2019).

The results further indicate that the coefficients of population and technology (research and development expenditure as a percentage of GDP) do not have statistically significant coefficients (see Tables 2-5). This implies that these variables have no significant impact on environmental degradation. The result of the effect of population on the environment may be explained by the insignificant population growth among industrialized countries (see World Bank, 2020), with a number of the countries experiencing zero growth rate. As a result, on the average, the effect of population on the environment seems mute. The outcome of the technology variable may also be explained by the fact that proxy for technology used is not specifically environmental technology.

\subsubsection{Sensitivity analyses}

In further analyses, we repeat the estimations of Tables 2-5 while excluding G-7 countries (Canada, France, Germany, Italy, Japan, the United Kingdom and the United States). Considering that the G-7 countries are the largest developed economies in the world, their characteristics may affect the direction of the results. We present the results excluding the G-7 countries in Tables 69. The results of $\mathrm{CD}$, panel unit root and slope homogeneity tests relating to the sensitivity analyses are not reported in order to save space but are available on request. The results of the overall measure of globalization remain qualitatively similar, where globalization reduces environmental degradation, but this is driven by the de jure component.

\section{[Table 6 here]}




\section{[Table 7 here]}

The results of economic globalization differ a bit from the entire sample as displayed in Table 7. The negative effect of economic globalization is not driven by actual flows and activities (de facto) but rather the policies, conditions and institutions surrounding the flow and activities (de jure). This implies that the de facto component of economic globalization is highly driven by these G-7 countries. This is not surprising as the G-7 countries are important global trade and financial players: nearly a third of all exports globally emanate from one of the G-7 countries and 35\% of all goods and services imported have a G-7 destination (Federal Statistical Office of Germany, 2015). These countries also account for about a third of global economic output. The results of social and political globalization are qualitatively consistent with the results for the entire sample.

\section{[Table 8 here] \\ [Table 9 here]}

Regarding the control variables, affluence comes out similar (in direction and significance) to the whole sample. Similarly, like the whole sample results, population largely remains statistically insignificant. Excluding the G-7 countries, the technology variable turns statistically significant (5\% and 10\%) in some of the estimations (especially in overall globalization, economic and political globalization). Though not strong, the results show that marginal increase in technology (research and development) is associated with a reduction in environmental degradation.

\section{Conclusion}

In this study, we examined the effect of overall globalization and its various components economic, social and political - on environmental degradation using a sample of 27 selected industrialized countries over the period 1991-2016. More importantly, we distinguish between the de facto and de jure measures of overall, economic, social and political globalization to conduct disaggregated analyses. To the best of our knowledge, we are the first to study of globalization and environmental degradation making distinction between the de facto and de jure elements of globalization. Departing from the use of pollutant-based measures widely applied in many previous studies, we use ecological footprint as proxy for environmental degradation. We extend the STIRPAT model by incorporating globalization and estimate this model with the AMG estimation approach. We find that overall and economic globalization have a negative and statistically significant effect on environmental degradation. By the same token, we find that the effect of social and political globalization on environmental degradation is negative albeit insignificantly. Turning attention to the de facto and de jure measures, we find that, while both de facto and de jure overall globalization exert a dampening effect on environmental degradation, only the de jure measure of overall globalization is statistically significant. The de facto and de jure economic globalization are found to have negative and statistically significant effect. While de facto social and political globalization have a positive and statistically insignificant effect, their de jure measures have negative effect with only social globalization being statistically significant. The aforementioned findings remain consistent with the exclusion of G-7 countries, except de facto economic globalization.

\section{Policy implications}


In line with the findings of the study, it is recommended that industrialized countries, though majority of them are greatly globalized, should seek to globalize the more as generally globalization is found to reduce environmental degradation. In the light of this, the industrialized countries should boost policies, resources, conditions and institutions that facilitate flows and activities between them and other countries. Increase in trade and financial openness with other countries should be given high priority. With their enormous resources, they can take the lead in economically globalizing the world through trade and FDI flows. In doing that, the need to enact policies that reduce international trade and capital restrictions becomes important. Social globalization is also another area that can be bolstered in generally improving overall globalization. In this regard, policies that aid international migration and international flows of ideas, information and culture should also be treated as priority. Going forward, future research may search for thresholds for the globalization-environmental degradation nexus. We believe this would help to unearth possible nonlinearities in the globalization-environmental degradation nexus in industrialized countries.

\section{References}

Acheampong, A.O., Adams, S., Boateng, E., 2019. Do globalization and renewable energy contribute to carbon emissions mitigation in Sub-Saharan Africa? Sci. Total Environ. 677, 436-446.

Akadiri, S.S., Alkawfi, M.M., Uğural, S., Akadiri, A.C., 2019. Towards achieving environmental sustainability target in Italy: the role of energy, real income and globalization. Sci. Total Environ. 671, 1293-1301.

Akadiri, S.S., Alola, A.A., Bekun, F.V., Etokakpan, M.U., 2020. Does electricity consumption and globalization increase pollutant emissions? Implications for environmental sustainability target for China. Environ. Sci. Pollut. Res. https://doi.org/10.1007/s11356-020-08784-3

Alagidede, P., Adu, G., Frimpong, P.B., 2016. The effect of climate change on economic growth: evidence from Sub-Saharan Africa. Environ. Econ. Policy Stud. 183, 417-436.

Aluko, O.A., Obalade, A. A., 2020. Financial development and environmental quality in subSaharan Africa: is there a technology effect? Sci. Total Environ. 747, 141515.

Baloch, M.A., Ozturk, I., Bekun, F.V., Khan, D., 2020. Modelling the dynamic linkage between financial development, energy innovation, and environmental quality: does globalization matter? Bus. Strategy Environ. https://doi.org/10.1002/bse.2615

Balsalobre-Lorente, D., Driha, O.M., Shahbaz, M., Sinha, A., 2020. The effects of tourism and globalization over environmental degradation in developed countries. Environ. Sci. Pollut. Res. 27, 7130-7144.

Baltagi, B.H., Demetriades, P.O., Law, S.H., 2009. Financial development and openness: evidence from panel data. J. Dev. Econ. 89, 285-296.

Bu, M., Lin, C.T., Zhang, B., 2016. Globalization and climate change: new empirical panel data evidence. J. Econ. Surv. 30, 577-595. 
Christmann, P., Taylor, G., 2001. Globalization and the environment: determinants of firm selfregulation in China. J. Int. Bus. Stud. 32, 439-458.

Cole, M.A., 2006. Does trade liberalization increase national energy use? Econ. Lett. 92, 108-112.

Dietz, T., Rosa, E. A. 1994. Rethinking the environmental impacts of population, affluence and technology. Hum. Ecol. Rev. 1, 277-300.

Destek, M.A., 2020. Investigation on the role of economic, social, and political globalization on environment: evidence from CEECs. Environ. Sci. Pollut. Res. 27, 33601-33614.

Dong, K., Dong, X., Dong, C., 2019. Determinants of the global and regional $\mathrm{CO}_{2}$ emissions: What causes what and where? Appl. Econ. 51, 5031-5044.

Dreher, A., 2006. Does globalization affect growth? Evidence from a new index of globalization. Appl. Econ. 38, 1091-1110.

Eberhardt, M., Bond, S., 2009. Cross-section dependence in nonstationary panel models: a novel estimator. MPRA paper no. 17870. http://mpra.ub.uni-muenchen.de/17870/.

Eberhardt, M., Helmers, C., Strauss, H., 2013. Do spillovers matter when estimating private returns to R\&D? Rev. Econ. Stat. 95, 436-448.

Federal Statistical Office of Germany, 2015. Federal Statistical Office, G7 in Figures, 2015. https://ec.europa.eu/eurostat/documents/7330775/7339485/G7InFiguresMay2015/0578de75-f33c-4e45-92cb-a6ba30bd8fbc

Feld, L.P., Voigt, S., 2003. Economic growth and judicial independence: cross-country evidence using a new set of indicators. European J. Pol. Econ. 19, 497-527.

Frankel, J., Rose, A., 2002. An estimate of the effect of common currencies on trade and income. Q. J. Econ. 117, 437-466.

Grossman, G.M., Krueger, A.B., 1991. Environmental impacts of a North American free trade agreement. Working Paper No. 3914. National Bureau of Economic Research, Cambridge.

Gygli, S., Haelg, F., Potrafke, N., Sturm, J.E., 2019. The KOF globalisation index-revisited. Rev. Int. Org. 14, 543-574.

Haines, A., Patz, J.A., 2004. Health effects of climate change. JAMA 29, 99-103.

Harbaugh, W.T., Levinson, A., Wilson, D.M., 2002. Reexamining the empirical evidence for an environmental Kuznets curve. Rev. Econ. Stat. 84, 541-551.

Haseeb, A., Xia, E., Saud, S., Ahmad, A., Khurshid, H., 2019. Does information and communication technologies improve environmental quality in the era of globalization? An empirical analysis. Environ. Sci. Pollut. Res. 26, 8594-8608.

Hernandez-Vega, M., 2019. Estimating capital flows to emerging market economies with heterogeneous panels. Macroeconomic Dynamics, 23, 2068-2088. 
Jayadevappa, R., Chhatre, S., 2000. International trade and environmental quality: a survey. Ecol. Econ. 32, 175-194.

Jevons, W.S. (1866). The Coal Question: An Inquiry Concerning the Progress of the Nation, and the Probable Exhaustion of our Coal-Mines. Macmillan, London.

Khan, D., Ullah, A., 2019. Testing the relationship between globalization and carbon dioxide emissions in Pakistan: does environmental Kuznets curve exist? Environ. Sci. Pollut. Res. 26, 15194-15208.

Khan, S. A. R., Yu, Z., Golpîra, H., Sharif, A., Mardani, A. 2020. A state-of-the-art review and meta-analysis on sustainable supply chain management: Future research directions. J. Clean. Prod, 123357.

Khan, S. A. R., Sharif, A., Golpîra, H., Kumar, A. 2019. A green ideology in Asian emerging economies: From environmental policy and sustainable development. Sust. Dev. 27(6), 1063-1075.

Khan, S. A. R., Zhang, Y., Kumar, A., Zavadskas, E., Streimikiene, D. 2020. Measuring the impact of renewable energy, public health expenditure, logistics, and environmental performance on sustainable economic growth. Sust. Dev. 28, 833-843

Khan, S. A.R., Yu, Z. 2020. Assessing the eco-environmental performance: an PLS-SEM approach with practice-based view. Int. J. Logist. Res. Appl. 1-19.

Kose, M.A., Prasad, E., Rogoff, K., Wei, S.J., 2009. Financial globalization: a reappraisal. IMF Staff Papers 56, 8-62.

Le, H.P., Ozturk, I., 2020. The impacts of globalization, financial development, government expenditures, and institutional quality on $\mathrm{CO}_{2}$ emissions in the presence of environmental Kuznets curve. Environ. Sci. Pollut. Res. 27, 22680-22697.

Li, K., Lin, B., 2015. Impacts of urbanization and industrialization on energy consumption/CO2 emissions: does the level of development matter? Renew. Sust. Energy Rev. 52, 1107-1122.

Lindsey, R., 2020. Climate Change: Global Sea Level. https://www.climate.gov/newsfeatures/understanding-climate/climate-change-global-sea-level

Lv, Z., Xu, T., 2018. Is economic globalization good or bad for the environmental quality? New evidence from dynamic heterogeneous panel models. Technological Forecasting \& Social Change, 137, 340-343.

Martens, P., Caselli, M., De Lombaerde, P., Figge, L., Scholte, J.A., 2015. New directions in globalization indices. Globalizations 12, 217-228.

Martínez-Zarzoso, I., Bengochea-Morancho, A., Morales-Lage, R., 2007. The impact of population on $\mathrm{CO}_{2}$ emissions: evidence from European countries. Environ. Resour. Econ. 38, 497-512. 
Nguyen, T.T., Pham, T.A.T., Tram, H.T.X., 2020. Role of information and communication technologies and innovation in driving carbon emissions and economic growth in selected G-20 countries. J. Environ. Manag. 261,110162.

Opoku, E.E.O., Boachie, M.K., 2020. The environmental impact of industrialization and foreign direct investment. Energy Policy 137, 111178.

Pesaran, M.H., 2004. General Diagnostic Tests for Cross Section Dependence. IZA Discussion Paper No. 1240. The Institute for the Study of Labor, Bonn.

Pesaran, M.H., 2007. A simple panel unit root test in the presence of cross- section dependence. J. Appl. Econ. 22, 265-312.

Pesaran, M.H., Smith, R., 1995. Estimating long-run relationships from dynamic heterogeneous panels. J. Econ. 68, 79-113.

Pesaran, M.H., Yamagata, T., 2008. Testing for slope homogeneity in large panels. J. Econ. 142, 50-93.

Pesaran, M.H., Ullah, A., Yamagata, T., 2008. A bias- adjusted LM test of error cross- section independence. Econ. J. 11, 105-127.

Phong, L.H., 2019. Globalization, financial development, and environmental degradation in the presence of environmental Kuznets curve: evidence from ASEAN-5 countries. Int. J. Energy Econ. Policy 9, 40-50.

Quinn, D.P., Schindler, M., Toyoda, M.A., 2011. Assessing measures of financial openness and integration. IMF Econ. Rev. 59, 488-522.

Rafindadi, A.A., Usman, O., 2019. Globalization, energy use, and environmental degradation in South Africa: Startling empirical evidence from the Maki-cointegration test. J. Environ. Manag. 244, 265-275.

Ritchie, H., Roser, M., 2020. $\mathrm{CO}_{2}$ and Greenhouse Gas Emissions. https://ourworldindata.org/co2-and-other-greenhouse-gas-emissions

Sabir, S., Gorus, M.S., 2019. The impact of globalization on ecological footprint: empirical evidence from the South Asian countries. Environ. Sci. Pollut. Res., 26, 33387-33398.

Saud, S., Chen, S., Haseeb, A., 2020. The role of financial development and globalization in the environment: accounting ecological footprint indicators for selected one-belt-one-road initiative countries. J. Clean. Prod. 250, 119518.

Shahbaz, M., Mahalik, M.K., Shahzad, S.J.H., Hammoudeh, S., 2019. Testing the globalizationdriven carbon emissions hypothesis. Int. Econ. 158, 25-38.

Shahbaz, M., Mallick, H., Mahalik, M.K., Loganathan, N., 2015. Does globalization impede environmental quality in India? Ecol. Indicat. 52, 379-393. 
Shahbaz, M., Shahzad, S.J.H., Mahalik, M.K., 2018. Is globalization detrimental to $\mathrm{CO}_{2}$ emissions in Japan? New threshold analysis. Environ. Model. Assess. 23, 557-568.

Shahbaz, M., Solarin, S.A., Ozturk, I., 2016. Environmental Kuznets curve hypothesis and the role of globalization in selected African countries. Ecol. Indicat. 67, 623-636.

Sharif, A., Godil, D.I., Xu, B., Sinha, A., Khan, S.A.R., Jermsittiparsert, K., 2020. Revisiting the role of tourism and globalization in environmental degradation in China: fresh insights from the quantile ARDL approach. J. Clean. Prod. 272, 122906.

Shujah-ur-Rahman, Chen, S., Saud, S., Bano, S., Haseeb, A., 2019. The nexus between financial development, globalization, and environmental degradation: fresh evidence from Central and Eastern European Countries. Environ. Sci. Pollut. Res. 26, 24733-24747.

Suki, N.M., Sharif, A., Afshan, S., Suki, N.M., 2020. Revisiting the environmental Kuznets curve in Malaysia: the role of globalization in sustainable environment. J. Clean. Prod., 264, 121669.

Tsurumi, T., Managi, S., 2010. Decomposition of the environmental Kuznets curve: scale, technique, and composition effects. Environ. Econ. Policy Stud. 11, 19-36.

Ulucak, Z.Ş., İlkay, S.Ç., Özcan, B., Gedikli, A., 2020. Financial globalization and environmental degradation nexus: evidence from emerging economies. Resour. Policy 67, 101698.

Usman, O., Olanipekun, I.O., Iorember, P.T., Abu-Goodman, M., 2020. Modelling environmental degradation in South Africa: the effects of energy consumption, democracy, and globalization using innovation accounting tests. Environ. Sci. Pollut. Res. 27, 8334-8349.

Voigt, S., Gutmann, J., Feld, L.P., 2015. Economic growth and judicial independence, a dozen years on: evidence using an updated set of indicators. European J. Pol. Econ. 38, 197-2011.

Wackernagel, M., Kitzes, J., 2008. Ecological footprint. U: Encyclopedia of Ecology (S. E. Jørgensen, BD Fath, ur).

Wang, Z., Rasool, Y., Asghar, M.M., Wang, B., 2019. Dynamic linkages among CO 2 emissions, human development, financial development, and globalization: empirical evidence based on PMG long-run panel estimation. Environ. Sci. Pollut. Res. 26, 36248-36263.

Wijen, F., Van Tulder, R., 2011. Integrating environmental and international strategies in a world of regulatory turbulence. California Manag. Rev. 53, 23-46.

World Bank (2020a). Population Growth (annual \%) - OECD members. World Bank. https://data.worldbank.org/indicator/SP.POP.GROW?locations=OE\&most_recent_value_d $\underline{\text { esc }=\text { true }}$

World Bank (2020b). World Bank Country and Lending Group. https://datahelpdesk.worldbank

Xu, Z., Baloch, M.A., Meng, F., Zhang, J., Mahmood, Z., 2018. Nexus between financial development and $\mathrm{CO}_{2}$ emissions in Saudi Arabia: analyzing the role of globalization. Environ. Sci. Pollut. Res. 25, 28378-28390. 
Zafar, M.W., Saud, S., Hou, F., 2019. The impact of globalization and financial development on environmental quality: evidence from selected countries in the Organization for Economic Co-operation and Development (OECD). Environ. Sci. Pollut. Res. 26, 13246-13262.

Zaidi, S.A.H., Zafar, M.W., Shahbaz, M., Hou, F., 2019. Dynamic linkages between globalization, financial development and carbon emissions: evidence from Asia Pacific Economic Cooperation countries. J. Clean. Prod. 228, 533-543. 
Table 1

Summary of empirical studies on the effect of globalization on environmental degradation

\begin{tabular}{|c|c|c|c|c|c|}
\hline Empirical study & Sample/Time period & $\begin{array}{c}\text { EKC } \\
\text { context }\end{array}$ & $\begin{array}{l}\text { Estimation } \\
\operatorname{method}(\mathrm{s})\end{array}$ & $\begin{array}{c}\text { Environmental } \\
\text { degradation measure(s) }\end{array}$ & Globalization measure(s)/Effect \\
\hline Acheampong, Adams and & 46 SSA countries & Yes & FE, RE, IV-GMM, & $\mathrm{CO}_{2}$ emissions & Trade openness (positive) \\
\hline Boateng (2019) & 1980-2015 & & Dynamic FE & & FDI inflows (negative) \\
\hline Akadiri, Alkawfi, Uğural and & Italy & No & ARDL & $\mathrm{CO}_{2}$ emissions & KOF overall globalization index (negative) \\
\hline Akadiri (2019) & $1970-2014$ & & & & \\
\hline Akadiri, Alola, Bekun and & China & No & ARDL & $\mathrm{CO}_{2}$ emissions & KOF overall globalization index (negative) \\
\hline Etokakpan (2020) & 1970-2014 & & & & \\
\hline $\begin{array}{l}\text { Baloch, Ozturk, Bekun and } \\
\text { Khan }(2020)\end{array}$ & $\begin{array}{c}27 \text { OECD countries } \\
1990-2017\end{array}$ & Yes & PMG & GHG emissions & KOF overall globalization index (negative) \\
\hline $\begin{array}{l}\text { Balsalobre-Lorente, Driha, } \\
\text { Shahbaz and Sinha (2020) }\end{array}$ & $\begin{array}{c}24 \text { OECD countries } \\
\text { 1994-2014 }\end{array}$ & Yes & FMOLS & $\mathrm{CO}_{2}$ emissions & KOF overall globalization index (positive) \\
\hline $\mathrm{Bu}$, Lin and Zhang (2016) & $\begin{array}{c}166 \text { countries } \\
1990-2009\end{array}$ & Yes & FE, 2SLS & $\mathrm{CO}_{2}$ emissions & $\begin{array}{l}\text { KOF economic globalization index (positive) } \\
\text { KOF social globalization index (positive) } \\
\text { KOF political globalization index (positive) }\end{array}$ \\
\hline Destek (2020) & $\begin{array}{l}12 \text { CEE countries } \\
\text { 1995-2015 }\end{array}$ & Yes & AMG & $\mathrm{CO}_{2}$ emissions & $\begin{array}{l}\text { KOF overall globalization index (positive) } \\
\text { KOF economic globalization index (positive) } \\
\text { KOF social globalization index (insignificant) } \\
\text { KOF political globalization index (negative) }\end{array}$ \\
\hline $\begin{array}{l}\text { Haseeb, Xia, Saud, Ahmad and } \\
\text { Khursid (2019) }\end{array}$ & $\begin{array}{l}\text { BRICS countries } \\
\text { 1994-2014 }\end{array}$ & No & DSUR & $\mathrm{CO}_{2}$ emissions & KOF overall globalization index (positive) \\
\hline Khan and Ullah (2019) & $\begin{array}{l}\text { Pakistan } \\
\text { 1975-2014 }\end{array}$ & Yes & ARDL & $\mathrm{CO}_{2}$ emissions & $\begin{array}{l}\text { KOF economic globalization index (positive) } \\
\text { KOF social globalization index (positive) } \\
\text { KOF political globalization index (positive) }\end{array}$ \\
\hline Le and Ozturk (2020) & $\begin{array}{c}47 \text { emerging and } \\
\text { developing countries } \\
1990-2014\end{array}$ & Yes & $\begin{array}{l}\text { CCEMG, AMG, } \\
\text { DCCE }\end{array}$ & $\mathrm{CO}_{2}$ emissions & KOF overall globalization index (positive) \\
\hline Lv and Xu (2018) & $\begin{array}{l}15 \text { emerging countries } \\
1970-2012\end{array}$ & No & $\begin{array}{l}\mathrm{MG}, \mathrm{AMG} \\
\mathrm{CCEMG}\end{array}$ & $\mathrm{CO}_{2}$ emissions & KOF economic globalization index (negative) \\
\hline Phong (2019) & $\begin{array}{c}\text { ASEAN-5 countries } \\
1971-2014\end{array}$ & Yes & FE, RE & $\mathrm{CO}_{2}$ emissions & $\begin{array}{l}\text { KOF overall globalization index (positive) } \\
\text { KOF economic globalization index (positive) } \\
\text { KOF social globalization index (positive) } \\
\text { KOF political globalization index (insignificant) }\end{array}$ \\
\hline Rafindadi and Usman (2019) & $\begin{array}{l}\text { South Africa } \\
1971-2014\end{array}$ & Yes & FMOLS & $\mathrm{CO}_{2}$ emissions & KOF overall globalization index (negative) \\
\hline Sabir and Gorus (2019) & $\begin{array}{l}5 \text { South Asian countries } \\
\text { 1975-2017 }\end{array}$ & Yes & Panel ARDL & Ecological footprint & $\begin{array}{c}\text { FDI inflows (positive) } \\
\text { Trade openness (positive) } \\
\text { KOF overall globalization index (positive) }\end{array}$ \\
\hline
\end{tabular}


Saud, Chen and Haseeb (2020)

Shahbaz, Solarin and Ozturk (2016)

Sharif, Godil, Xu, Sinha, Khan and Jermsittiparsert (2020)

Shujah-ur-Rahman, Chen, Saud, Bano and Haseeb (2019) Suki, Sharif, Afshan and Suki (2020)

Ulucak, İlkay, Özcan and Gedikli (2020)

Usman, Olanipekun, Iorember and Abu-Goodman (2020)

Wang, Rasool, Asghar and

Wang (2019)

$\mathrm{Xu}$, Baloch, Meng, Zhang and

Mahmood (2018)

Zafar, Saud and Hou (2019)

Zaidi, Zafar, Shahbaz and Hou (2019)
49 OBOR countries 1990-2014

19 African countries 1971-2012

China

1978Q1-2017Q4

16 CEE countries 1980-2016

Malaysia

1970-2018

15 emerging countries

1974-2016

South Africa

1971-2014

25 OECD countries

1990-2014

Saudi Arabia

1971-2016

27 OECD countries 1990-2014

17 APEC countries
No

PMG

ARDL

Yes

Yes Quantile ARDL

Yes

Yes

Yes

Yes

No

No

Yes

Yes

DSUR

Quantile ARDL

PMG

FMOLS

PMG

ARDL
Ecological footprint Carbon footprint

$\mathrm{CO}_{2}$ emissions

$\mathrm{CO}_{2}$ emissions

CUP-BC, CUP-FM

CUP-BC, CUP-FM
Ecological footprint $\mathrm{CO}_{2}$ emissions

GHG emissions

$\mathrm{CO}_{2}$ emissions

Ecological footprint

Ecological footprint

$\mathrm{CO}_{2}$ emissions

$\mathrm{CO}_{2}$ emissions

$\mathrm{CO}_{2}$ emissions

$\mathrm{CO}_{2}$ emissions

$\mathrm{CO}_{2}$ emissions
KOF overall globalization index (negative)

KOF overall globalization index (mixed)

KOF overall globalization index (mixed)

KOF overall globalization index (negative)

KOF overall globalization index (positive) KOF economic globalization index (positive)

KOF social globalization index (negative)

KOF political globalization index (negative)

KOF financial globalization index (negative)

KOF overall globalization index (negative)

KOF overall globalization index (positive)

KOF overall globalization index (insignificant) KOF economic globalization index (positive) KOF social globalization index (insignificant) KOF political globalization index (positive)

KOF overall globalization index (negative)

KOF overall globalization index (negative)

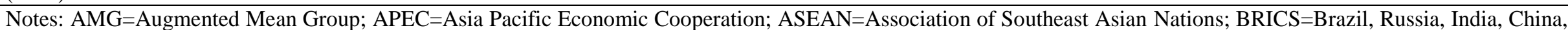

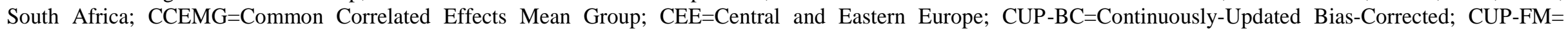

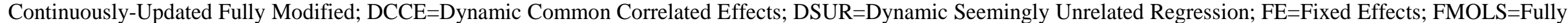

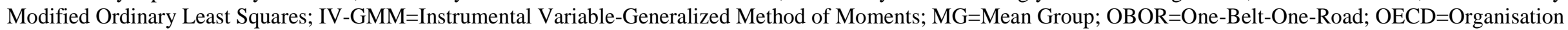
for Economic Co-operation and Development; PMG=Pooled Mean Group; RE=Random Effects; SSA=Sub-Saharan Africa; 2SLS=Two Stage Least Squares 
Table 2

Overall globalization and environmental degradation

\begin{tabular}{|c|c|c|c|c|c|c|}
\hline \multirow[b]{2}{*}{ Constant } & \multicolumn{2}{|c|}{ Overall } & \multicolumn{2}{|c|}{ De facto } & \multicolumn{2}{|c|}{ De jure } \\
\hline & $\begin{array}{c}2.380 \\
(0.757)\end{array}$ & $\begin{array}{l}-16.253 \\
(0.189)\end{array}$ & $\begin{array}{c}6.661 \\
(0.292)\end{array}$ & $\begin{array}{l}-16.143 \\
(0.332)\end{array}$ & $\begin{array}{c}3.189 \\
(0.666)\end{array}$ & $\begin{array}{l}-5.628 \\
(0.751)\end{array}$ \\
\hline $\ln P$ & $\begin{array}{l}-0.324 \\
(0.526)\end{array}$ & $\begin{array}{c}-0.366 \\
(0.601)\end{array}$ & $\begin{array}{c}-0.561 \\
(0.171)\end{array}$ & $\begin{array}{c}0.575 \\
(0.545)\end{array}$ & $\begin{array}{c}-0.336 \\
(0.504)\end{array}$ & $\begin{array}{l}-0.122 \\
(0.905)\end{array}$ \\
\hline $\ln \mathrm{A}$ & $\begin{array}{c}0.851 * * * \\
(0.000)\end{array}$ & $\begin{array}{c}0.823 * * * \\
(0.000)\end{array}$ & $\begin{array}{c}0.576 * * * \\
(0.001)\end{array}$ & $\begin{array}{c}0.833 * * * \\
(0.000)\end{array}$ & $\begin{array}{c}0.810 * * * \\
(0.000)\end{array}$ & $\begin{array}{c}0.733 * * * \\
(0.000)\end{array}$ \\
\hline $\ln \mathrm{T}$ & $\begin{array}{l}-0.083 \\
(0.304)\end{array}$ & $\begin{array}{l}-0.108 \\
(0.240)\end{array}$ & $\begin{array}{l}-0.055 \\
(0.500)\end{array}$ & $\begin{array}{l}-0.084 \\
(0.316)\end{array}$ & $\begin{array}{l}-0.071 \\
(0.392)\end{array}$ & $\begin{array}{c}-0.082 \\
(0.373)\end{array}$ \\
\hline $\operatorname{lnOG}$ & $\begin{array}{c}-0.814 * * * \\
(0.002)\end{array}$ & $\begin{array}{c}-0.544 * * \\
(0.024)\end{array}$ & $\begin{array}{l}-0.323 \\
(0.155)\end{array}$ & $\begin{array}{l}-0.351 \\
(0.210)\end{array}$ & $\begin{array}{c}-0.632 * * * \\
(0.001)\end{array}$ & $\begin{array}{l}-0.289 \\
(0.108)\end{array}$ \\
\hline CDP & $\begin{array}{c}0.686^{* * * *} \\
(0.000)\end{array}$ & $\begin{array}{c}0.538 * * * \\
(0.002)\end{array}$ & $\begin{array}{c}0.687 * * * \\
(0.000)\end{array}$ & $\begin{array}{c}0.451^{* * *} * \\
(0.002)\end{array}$ & $\begin{array}{c}0.695^{* * *} * \\
(0.000)\end{array}$ & $\begin{array}{c}0.559 * * * \\
(0.001)\end{array}$ \\
\hline Trend & No & Yes & No & Yes & No & Yes \\
\hline Wald $x^{2}$ & $0.000 * * *$ & $0.000 * * *$ & $0.006 * * *$ & $0.001 * * *$ & $0.000 * * *$ & $0.003 * * *$ \\
\hline Root mean squared error & 0.072 & 0.068 & 0.072 & 0.067 & 0.072 & 0.069 \\
\hline No. of groups (countries) & 27 & 27 & 27 & 27 & 27 & 27 \\
\hline
\end{tabular}

Notes: Values in brackets are p-values and $* * *, * *$ and $*$ indicate p-value does not exceed $0.01,0.05$ and 0.1 , respectively. CDP denotes common dynamic process and $\mathrm{p}$-value is reported for Wald $\mathrm{x}^{2}$.

Table 3

Economic globalization and environmental degradation

\begin{tabular}{|c|c|c|c|c|c|c|}
\hline \multirow{3}{*}{ Constant } & \multicolumn{2}{|c|}{ Overall } & \multicolumn{2}{|c|}{ De facto } & \multicolumn{2}{|c|}{ De jure } \\
\hline & 10.799 & -1.675 & 7.806 & -3.597 & 9.724 & -11.738 \\
\hline & $(0.124)$ & $(0.877)$ & $(0.308)$ & $(0.825)$ & $(0.142)$ & $(0.419)$ \\
\hline \multirow[t]{2}{*}{$\ln \mathrm{P}$} & $-0.772 *$ & -0.133 & -0.686 & 0.177 & $-0.785^{*}$ & 0.487 \\
\hline & $(0.099)$ & $(0.826)$ & $(0.206)$ & $(0.840)$ & $(0.428)$ & $(0.472)$ \\
\hline \multirow[t]{2}{*}{$\ln \mathrm{A}$} & $0.790 * * *$ & $0.828 * * *$ & $0.470 * *$ & $0.723 * * *$ & $0.762 * * *$ & $0.859 * * *$ \\
\hline & $(0.000)$ & $(0.000)$ & $(0.014)$ & $(0.001)$ & $(0.000)$ & $(0.000)$ \\
\hline \multirow[t]{2}{*}{$\ln T$} & -0.059 & -0.044 & -0.507 & -0.082 & -0.065 & -0.078 \\
\hline & $(0.422)$ & $(0.568)$ & $(0.534)$ & $(0.340)$ & $(0.460)$ & $(0.430)$ \\
\hline \multirow[t]{2}{*}{$\operatorname{lnEG}$} & $-0.484 * * *$ & $-0.206^{* * *}$ & $-0.170 * *$ & $-0.154 *$ & $-0.298 * * *$ & $-0.129 *$ \\
\hline & $(0.002)$ & $(0.007)$ & $(0.045)$ & $(0.083)$ & $(0.002)$ & $(0.072)$ \\
\hline \multirow[t]{2}{*}{ CDP } & $0.557 * * *$ & $0.369 * * *$ & $0.674 * * *$ & $0.428 * * *$ & $0.624 * * *$ & $0.444 * * *$ \\
\hline & $(0.000)$ & $(0.007)$ & $(0.000)$ & $(0.002)$ & $(0.000)$ & $(0.005)$ \\
\hline Trend & No & Yes & No & Yes & No & Yes \\
\hline Wald $x^{2}$ & $0.000 * * *$ & $0.000 * * *$ & $0.017 * *$ & $0.004 * * *$ & $0.000 * * *$ & $0.000 * * *$ \\
\hline Root mean squared error & 0.071 & 0.068 & 0.070 & 0.067 & 0.074 & 0.070 \\
\hline No. of groups (countries) & 27 & 27 & 27 & 27 & 27 & 27 \\
\hline
\end{tabular}

Note: Values in brackets are p-values and ***, ** and * indicate p-value does not exceed $0.01,0.05$ and 0.1 , respectively. CDP denotes common dynamic process and $\mathrm{p}$-value is reported for Wald $\mathrm{x}^{2}$. 
Table 4

Social globalization and environmental degradation

\begin{tabular}{|c|c|c|c|c|c|c|}
\hline \multirow{3}{*}{ Constant } & \multicolumn{2}{|c|}{ Overall } & \multicolumn{2}{|c|}{ De facto } & \multicolumn{2}{|c|}{ De jure } \\
\hline & -5.820 & -18.018 & -0.884 & -11.123 & 0.348 & -19.955 \\
\hline & $(0.522)$ & $(0.144)$ & $(0.896)$ & $(0.435)$ & $(0.968)$ & $(0.132)$ \\
\hline \multirow[t]{2}{*}{$\ln \mathrm{P}$} & 0.212 & 0.758 & -0.226 & 0.387 & -0.053 & 0.927 \\
\hline & (0.709) & $(0.285)$ & $(0.607)$ & $(0.630)$ & $(0.925)$ & $(0.230)$ \\
\hline \multirow[t]{2}{*}{$\ln A$} & $0.700 * * *$ & $0.841 * * *$ & $0.710 * * *$ & $0.799 * * *$ & $0.548 * * *$ & $0.751 * * *$ \\
\hline & $(0.000)$ & $(0.000)$ & $(0.000)$ & $(0.000)$ & $(0.001)$ & $(0.000)$ \\
\hline \multirow[t]{2}{*}{$\ln \mathrm{T}$} & -0.034 & -0.078 & -0.027 & -0.045 & -0.041 & -0.080 \\
\hline & (0.609) & $(0.273)$ & $(0.711)$ & $(0.586)$ & $(0.585)$ & $(0.260)$ \\
\hline \multirow[t]{2}{*}{$\operatorname{lnSG}$} & -0.241 & -0.165 & 0.207 & 0.122 & -0.195 & $-0.356 * *$ \\
\hline & $(0.419)$ & $(0.589)$ & $(0.430)$ & $(0.759)$ & $(0.002)$ & $(0.031)$ \\
\hline \multirow[t]{2}{*}{ CDP } & $0.793 * * *$ & $0.706 * * *$ & $0.769 * * *$ & $0.637 * * *$ & $0.812 * * *$ & $0.632 * * *$ \\
\hline & $(0.000)$ & $(0.007)$ & $(0.000)$ & $(0.000)$ & $(0.000)$ & $(0.000)$ \\
\hline Trend & No & Yes & No & Yes & No & Yes \\
\hline Wald $x^{2}$ & $0.002 * * *$ & $0.001 * * *$ & $0.000 * * *$ & $0.003 * * *$ & $0.013 * *$ & $0.000 * * *$ \\
\hline Root mean squared error & 0.071 & 0.068 & 0.073 & 0.067 & 0.071 & 0.069 \\
\hline No. of groups (countries) & 27 & 27 & 27 & 27 & 27 & 27 \\
\hline
\end{tabular}

Notes: Values in brackets are p-values and $* * *, * *$ and * indicate p-value does not exceed $0.01,0.05$ and 0.1 , respectively. CDP denotes common dynamic process and $\mathrm{p}$-value is reported for Wald $\mathrm{x}^{2}$.

Table 5

Political globalization and environmental degradation

\begin{tabular}{|c|c|c|c|c|c|c|}
\hline \multirow{3}{*}{ Constant } & \multicolumn{2}{|c|}{ Overall } & \multicolumn{2}{|c|}{ De facto } & \multicolumn{2}{|c|}{ De jure } \\
\hline & 0.495 & -10.746 & 1.444 & -14.192 & -3.494 & -8.026 \\
\hline & $(0.950)$ & $(0.466)$ & $(0.839)$ & $(0.386)$ & $(0.716)$ & $(0.623)$ \\
\hline \multirow[t]{2}{*}{$\ln \mathrm{P}$} & -0.187 & 0.256 & -0.430 & 0.591 & -0.007 & 0.139 \\
\hline & $(0.715)$ & $(0.740)$ & $(0.345)$ & $(0.478)$ & (0.991) & $(0.878)$ \\
\hline \multirow[t]{2}{*}{$\ln A$} & $0.646 * * *$ & $0.733 * * *$ & $0.603 * * *$ & $0.742 * * *$ & $0.741 * * *$ & $0.674 * * *$ \\
\hline & $(0.000)$ & $(0.000)$ & $(0.000)$ & $(0.000)$ & $(0.000)$ & $(0.001)$ \\
\hline \multirow[t]{2}{*}{$\ln \mathrm{T}$} & -0.084 & -0.091 & -0.086 & -0.077 & -0.136 & -0.117 \\
\hline & $(0.328)$ & $(0.311)$ & $(0.313)$ & $(0.402)$ & $(0.114)$ & $(0.188)$ \\
\hline \multirow[t]{2}{*}{$\ln P G$} & -0.185 & -0.061 & 0.267 & 0.053 & -0.330 & -0.130 \\
\hline & $(0.335)$ & $(0.776)$ & $(0.148)$ & $(0.773)$ & $(0.179)$ & $(0.583)$ \\
\hline \multirow[t]{2}{*}{ CDP } & $0.735 * * *$ & $0.514 * * *$ & $0.751 * * *$ & $0.526^{* * *} *$ & $0.635 * * *$ & $0.493 * * *$ \\
\hline & $(0.000)$ & $(0.001)$ & $(0.000)$ & $(0.001)$ & $(0.000)$ & $(0.001)$ \\
\hline Trend & No & Yes & No & Yes & No & Yes \\
\hline Wald $x^{2}$ & $0.000 * * *$ & $0.004 * * *$ & $0.000 * * *$ & $0.003 * * *$ & $0.000 * * *$ & $0.007 * * *$ \\
\hline Root mean squared error & 0.073 & 0.068 & 0.074 & 0.069 & 0.072 & 0.068 \\
\hline No. of groups (countries) & 27 & 27 & 27 & 27 & 27 & 27 \\
\hline
\end{tabular}

Notes: Values in brackets are p-values and ***, ** and * indicate p-value does not exceed 0.01, 0.05 and 0.1, respectively. CDP denotes common dynamic process and $\mathrm{p}$-value is reported for Wald $\mathrm{x}^{2}$. 
Table 6

Overall globalization and environmental degradation (excluding G-7 countries)

\begin{tabular}{|c|c|c|c|c|c|c|}
\hline \multirow{3}{*}{ Constant } & \multicolumn{2}{|c|}{ Overall } & \multicolumn{2}{|c|}{ De facto } & \multicolumn{2}{|c|}{ De jure } \\
\hline & -7.715 & -7.954 & 5.712 & $-22.818 * *$ & -4.804 & -7.449 \\
\hline & $(0.185)$ & $(0.394)$ & $(0.470)$ & $(0.044)$ & $(0.615)$ & $(0.457)$ \\
\hline \multirow[t]{2}{*}{$\ln \mathrm{P}$} & 0.194 & 0.308 & -0.536 & 1.002 & 0.151 & 0.160 \\
\hline & $(0.634)$ & $(0.625)$ & $(0.323)$ & $(0.131)$ & $(0.817)$ & (0.809) \\
\hline \multirow[t]{2}{*}{$\ln A$} & $0.870 * * *$ & $0.819 * * *$ & $0.640 * * *$ & $0.816^{* * *}$ & $0.883 * * *$ & $0.697 * * *$ \\
\hline & $(0.000)$ & $(0.000)$ & $(0.006)$ & $(0.001)$ & $(0.000)$ & $(0.009)$ \\
\hline \multirow[t]{2}{*}{$\ln \mathrm{T}$} & $-0.190 * *$ & -0.147 & $-0.140 *$ & -0.080 & $-0.161 *$ & -0.142 \\
\hline & $(0.043)$ & $(0.123)$ & $(0.091)$ & $(0.335)$ & $(0.080)$ & $(0.178)$ \\
\hline \multirow[t]{2}{*}{$\operatorname{lnOG}$} & $-0.841 * *$ & $-0.526 *$ & -0.466 & -0.017 & $-0.662 * * *$ & -0.301 \\
\hline & $(0.010)$ & $(0.066)$ & $(0.141)$ & $(0.956)$ & $(0.000)$ & $(0.167)$ \\
\hline \multirow[t]{2}{*}{ CDP } & $0.680 * * *$ & $0.634 * * *$ & $0.652 * * *$ & $0.557 * * *$ & $0.696 * * *$ & $0.687 * * *$ \\
\hline & $(0.000)$ & $(0.000)$ & $(0.000)$ & $(0.000)$ & $(0.001)$ & $(0.000)$ \\
\hline Trend & No & Yes & No & Yes & No & Yes \\
\hline Wald $x^{2}$ & $0.000 * * *$ & $0.000 * * *$ & $0.009 * * *$ & $0.007 * * *$ & $0.000 * * *$ & $0.030 * *$ \\
\hline Root mean squared error & 0.082 & 0.079 & 0.083 & 0.078 & 0.083 & 0.080 \\
\hline No. of groups (countries) & 20 & 20 & 20 & 20 & 20 & 20 \\
\hline
\end{tabular}

Notes: Values in brackets are p-values and $* * *, * *$ and * indicate p-value does not exceed $0.01,0.05$ and 0.1 , respectively. CDP denotes common dynamic process and $\mathrm{p}$-value is reported for $\mathrm{Wald} \mathrm{x}^{2}$.

Table 7

Economic globalization and environmental degradation (excluding G-7 countries)

\begin{tabular}{|c|c|c|c|c|c|c|}
\hline \multirow{3}{*}{ Constant } & \multicolumn{2}{|c|}{ Overall } & \multicolumn{2}{|c|}{ De facto } & \multicolumn{2}{|c|}{ De jure } \\
\hline & 0.679 & 0.015 & 2.804 & -7.687 & -0.236 & -7.449 \\
\hline & $(0.922)$ & $(0.998)$ & $(0.686)$ & $(0.507)$ & $(0.972)$ & $(0.457)$ \\
\hline \multirow[t]{2}{*}{$\ln \mathrm{P}$} & -0.251 & -0.135 & -0.309 & 0.317 & -0.222 & 0.160 \\
\hline & $(0.623)$ & $(0.777)$ & $(0.565)$ & $(0.649)$ & $(0.640)$ & $(0.809)$ \\
\hline \multirow[t]{2}{*}{$\ln A$} & $0.801 * * *$ & $0.765 * * *$ & $0.452 * *$ & 0.630 *** & $0.819 * * *$ & $0.696 * * *$ \\
\hline & $(0.001)$ & $(0.000)$ & $(0.023)$ & $(0.003)$ & $(0.000)$ & $(0.009)$ \\
\hline \multirow[t]{2}{*}{$\ln T$} & -0.138 & -0.116 & -0.154 & -0.134 & $-0.155^{*}$ & -0.142 \\
\hline & $(0.122)$ & $(0.259)$ & $(0.128)$ & $(0.166)$ & (0.099) & $(0.178)$ \\
\hline \multirow[t]{2}{*}{$\operatorname{lnEG}$} & $-0.513 * * *$ & $-0.252 *$ & -0.205 & -0.105 & $-0.271 * * *$ & -0.301 \\
\hline & $(0.001)$ & $(0.060)$ & $(0.180)$ & $(0.525)$ & $(0.001)$ & $(0.167)$ \\
\hline \multirow{2}{*}{ CDP } & $0.603 * * *$ & $0.440 * * *$ & $0.657 * * *$ & $0.527 * * *$ & $0.627 * *$ & $0.687 * * *$ \\
\hline & $(0.001)$ & $(0.001)$ & $(0.000)$ & $(0.001)$ & $(0.014)$ & $(0.000)$ \\
\hline Trend & No & Yes & No & Yes & No & Yes \\
\hline Wald $x^{2}$ & $0.000 * * *$ & $0.002 * * *$ & $0.047 * *$ & $0.025 * *$ & $0.000 * * *$ & $0.030 * *$ \\
\hline Root mean squared error & 0.081 & 0.079 & 0.081 & 0.078 & 0.086 & 0.080 \\
\hline No. of groups (countries) & 20 & 20 & 20 & 20 & 20 & 20 \\
\hline
\end{tabular}

Notes: Values in brackets are p-values and $* * *, * *$ and * indicate p-value does not exceed $0.01,0.05$ and 0.1 , respectively. CDP denotes common dynamic process and $\mathrm{p}$-value is reported for $\mathrm{Wald}^{2}$. 
Table 8

Social globalization and environmental degradation (excluding G-7 countries)

\begin{tabular}{|c|c|c|c|c|c|c|}
\hline \multirow{3}{*}{ Constant } & \multicolumn{2}{|c|}{ Overall } & \multicolumn{2}{|c|}{ De facto } & \multicolumn{2}{|c|}{ De jure } \\
\hline & -10.995 & -17.178 & -3.481 & -17.424 & -4.563 & $-18.106^{*}$ \\
\hline & $(0.200)$ & $(0.105)$ & $(0.669)$ & $(0.185)$ & $(0.473)$ & $(0.079)$ \\
\hline \multirow[t]{2}{*}{$\ln \mathrm{P}$} & 0.403 & 0.869 & -0.237 & 0.729 & 0.118 & 0.957 \\
\hline & $(0.464)$ & $(0.225)$ & $(0.678)$ & $(0.381)$ & $(0.800)$ & $(0.168)$ \\
\hline \multirow[t]{2}{*}{$\ln A$} & $0.877 * * *$ & $0.777 * * *$ & $0.614 * * *$ & $0.696 * * *$ & $0.738 * * *$ & $0.868 * * *$ \\
\hline & $(0.000)$ & $(0.001)$ & $(0.000)$ & $(0.001)$ & $(0.001)$ & $(0.000)$ \\
\hline \multirow[t]{2}{*}{$\ln \mathrm{T}$} & -0.046 & -0.059 & -0.020 & -0.011 & -0.109 & -0.128 \\
\hline & $(0.465)$ & $(0.383)$ & $(0.745)$ & $(0.915)$ & $(0.162)$ & $(0.113)$ \\
\hline \multirow[t]{2}{*}{$\ln S G$} & -0.412 & -0.324 & 0.402 & 0.325 & $-0.620 * *$ & $-0.604 * * *$ \\
\hline & $(0.263)$ & (0.399) & $(0.312)$ & $(0.532)$ & $(0.016)$ & $(0.000)$ \\
\hline \multirow[t]{2}{*}{$\mathrm{CDP}$} & $0.763 * * *$ & $0.694 * * *$ & $0.753 * * *$ & $0.619 * * *$ & $0.740 * * *$ & $0.698 * * *$ \\
\hline & $(0.000)$ & $(0.002)$ & $(0.000)$ & $(0.002)$ & $(0.000)$ & $(0.001)$ \\
\hline Trend & No & Yes & No & Yes & No & Yes \\
\hline Wald $x^{2}$ & $0.001 * * *$ & $0.008 * * *$ & $0.000 * * *$ & $0.016^{* *}$ & $0.001 * * *$ & $0.000 * * *$ \\
\hline Root mean squared error & 0.082 & 0.079 & 0.073 & 0.079 & 0.083 & 0.081 \\
\hline No. of groups (countries) & 20 & 20 & 20 & 20 & 20 & 20 \\
\hline
\end{tabular}

Notes: Values in brackets are p-values and ***, ** and * indicate p-value does not exceed $0.01,0.05$ and 0.1 , respectively. CDP denotes common dynamic process and $\mathrm{p}$-value is reported for $\mathrm{Wald} \mathrm{x}^{2}$.

Table 9

Political globalization and environmental degradation (excluding G-7 countries)

\begin{tabular}{|c|c|c|c|c|c|c|}
\hline \multirow{3}{*}{ Constant } & \multicolumn{2}{|c|}{ Overall } & \multicolumn{2}{|c|}{ De facto } & \multicolumn{2}{|c|}{ De jure } \\
\hline & -5.031 & $-20.699 *$ & -9.966 & -17.520 & -8.434 & -15.359 \\
\hline & $(0.446)$ & $(0.086)$ & $(0.208)$ & $(0.183)$ & $(0.243)$ & $(0.142)$ \\
\hline \multirow[t]{2}{*}{$\ln \mathrm{P}$} & 0.075 & 0.789 & 0.226 & 0.570 & 0.212 & 0.551 \\
\hline & $(0.870)$ & $(0.241)$ & (0.689) & $(0.555)$ & $(0.658)$ & $(0.394)$ \\
\hline \multirow[t]{2}{*}{$\ln A$} & $0.723 * * *$ & $0.731 * * *$ & $0.743 * * *$ & $0.820 * * *$ & $0.729 * * *$ & $0.644 * * *$ \\
\hline & $(0.000)$ & $(0.002)$ & $(0.000)$ & $(0.000)$ & $(0.000)$ & $(0.002)$ \\
\hline \multirow[t]{2}{*}{$\ln T$} & $-0.162 *$ & -0.091 & $-0.167 * *$ & -0.106 & -0.168 & -0.128 \\
\hline & $(0.052)$ & $(0.292)$ & $(0.024)$ & $(0.238)$ & $(0.045)$ & $(0.150)$ \\
\hline \multirow[t]{2}{*}{$\ln P G$} & -0.317 & 0.024 & 0.306 & 0.297 & -0.191 & -0.120 \\
\hline & $(0.222)$ & $(0.923)$ & $(0.230)$ & $(0.285)$ & $(0.354)$ & $(0.503)$ \\
\hline \multirow[t]{2}{*}{ CDP } & $0.731 * * *$ & $0.605 * * *$ & $0.687 * * *$ & $0.605 * * *$ & $0.691 * * *$ & $0.631 * * *$ \\
\hline & $(0.000)$ & $(0.000)$ & $(0.001)$ & $(0.001)$ & $(0.000)$ & $(0.001)$ \\
\hline Trend & No & Yes & No & Yes & No & Yes \\
\hline Wald $x^{2}$ & $0.000 * * *$ & $0.014 * *$ & $0.000 * * *$ & $0.003 * * *$ & $0.000 * * *$ & $0.014 * *$ \\
\hline Root mean squared error & 0.084 & 0.081 & 0.086 & 0.082 & 0.083 & 0.079 \\
\hline No. of groups (countries) & 20 & 20 & 20 & 20 & 20 & 20 \\
\hline
\end{tabular}

Notes: Values in brackets are p-values and $* * *, * *$ and $*$ indicate p-value does not exceed $0.01,0.05$ and 0.1 , respectively. CDP denotes common dynamic process and $\mathrm{p}$-value is reported for $\mathrm{Wald} \mathrm{x}^{2}$. 


\section{Appendix}

Table A.1

List of countries and classifications

\begin{tabular}{|c|c|c|c|c|c|c|}
\hline Country & $\begin{array}{l}\text { Developed(D) } \\
/ \text { Emerging(E) }\end{array}$ & $\begin{array}{l}\text { OECD } \\
\text { member }\end{array}$ & $\begin{array}{c}\mathrm{EU} \\
\text { member }\end{array}$ & $\begin{array}{c}\text { G-7 } \\
\text { member }\end{array}$ & $\begin{array}{c}\text { G-20 } \\
\text { member }\end{array}$ & Income group $\dagger$ \\
\hline Australia & $\mathrm{D}$ & $\checkmark$ & $x$ & $x$ & $\checkmark$ & High-income \\
\hline Belgium & D & $\checkmark$ & $\checkmark$ & $x$ & $x$ & High-income \\
\hline Canada & $\mathrm{D}$ & $\checkmark$ & $x$ & $\checkmark$ & $\checkmark$ & High-income \\
\hline China & $\mathrm{E}$ & $x$ & $x$ & $x$ & $\checkmark$ & Upper-middle-income \\
\hline Denmark & $\mathrm{D}$ & $\checkmark$ & $\checkmark$ & $x$ & $x$ & High-income \\
\hline Finland & D & $\checkmark$ & $\checkmark$ & $x$ & $x$ & High-income \\
\hline France & D & $\checkmark$ & $\checkmark$ & $\checkmark$ & $\checkmark$ & High-income \\
\hline Germany & D & $\checkmark$ & $\checkmark$ & $\checkmark$ & $\checkmark$ & High-income \\
\hline Hungary & $\mathrm{E}$ & $\checkmark$ & $\checkmark$ & $x$ & $x$ & High-income \\
\hline Ireland & D & $\checkmark$ & $\checkmark$ & $x$ & $x$ & High-income \\
\hline Italy & $\mathrm{D}$ & $\checkmark$ & $\checkmark$ & $\checkmark$ & $\checkmark$ & High-income \\
\hline Japan & $\mathrm{D}$ & $\checkmark$ & $x$ & $\checkmark$ & $\checkmark$ & High-income \\
\hline Korea & $\mathrm{D}$ & $\checkmark$ & $x$ & $x$ & $\checkmark$ & High-income \\
\hline Mexico & $\mathrm{E}$ & $\checkmark$ & $x$ & $x$ & $\checkmark$ & Upper-middle-income \\
\hline Netherlands & D & $\checkmark$ & $\checkmark$ & $x$ & $x$ & High-income \\
\hline Norway & D & $\checkmark$ & $x$ & $x$ & $x$ & High-income \\
\hline Poland & D & $\checkmark$ & $\checkmark$ & $x$ & $x$ & High-income \\
\hline Portugal & D & $\checkmark$ & $\checkmark$ & $x$ & $x$ & High-income \\
\hline Romania & $\mathrm{D}$ & $x$ & $\checkmark$ & $x$ & $x$ & High-income \\
\hline Russia & E & $x$ & $\checkmark$ & $\checkmark$ & $\checkmark$ & Upper-middle-income \\
\hline Singapore & $\mathrm{D}$ & $x$ & $x$ & $x$ & $x$ & High-income \\
\hline Slovak Republic & D & $\checkmark$ & $\checkmark$ & $x$ & $x$ & High-income \\
\hline Spain & $\mathrm{D}$ & $\checkmark$ & $\checkmark$ & $x$ & $x$ & High-income \\
\hline Switzerland & $\mathrm{D}$ & $\checkmark$ & $x$ & $x$ & $x$ & High-income \\
\hline Turkey & $\mathrm{E}$ & $\checkmark$ & $x$ & $x$ & $\checkmark$ & Upper-middle-income \\
\hline United Kingdom & D & $\checkmark$ & $x$ & $x$ & $\checkmark$ & High-income \\
\hline United States & $\mathrm{D}$ & $\checkmark$ & $x$ & $\checkmark$ & $\checkmark$ & High-income \\
\hline
\end{tabular}

Notes: $\uparrow$ denotes income group based on World Bank (2020b); $\checkmark$ and $x$ respectively indicate Yes and No;

$\mathrm{OECD}=$ Organisation for Economic Co-operation and Development; EU=European Union 
Table A. 2

Data measurement and sources

\begin{tabular}{|c|c|c|c|c|}
\hline Variable & Data measurement & Data description & Source & $\begin{array}{l}\text { Expected } \\
\text { outcome }\end{array}$ \\
\hline Environmental degradation & Ecological footprint per capita & $\begin{array}{l}\text { It is the amount of biologically productive area } \\
\text { of a country used by the population for crop } \\
\text { production, animal grazing, timber regeneration, } \\
\text { fishery, building of physical infrastructure and } \\
\text { absorption of gas emissions from energy } \\
\text { consumption divided by population size. }\end{array}$ & GFN & \\
\hline Population & Population size & $\begin{array}{l}\text { Number of residents in a country irrespective of } \\
\text { legal status or citizenship. }\end{array}$ & WDI & + \\
\hline Affluence & GDP per capita (in constant 2010 US dollar) & GDP divided by population. & WDI & + \\
\hline Technology & $\begin{array}{l}\text { Share of gross domestic spending on } \\
\text { research and development (R\&D) in GDP }\end{array}$ & $\begin{array}{l}\text { Total amount of funds expended on R\&D } \\
\text { activities by resident companies, research } \\
\text { institutes, university and government } \\
\text { laboratories in a country as percentage of GDP. }\end{array}$ & OECD & $+/-$ \\
\hline Overall globalization (overall) & KOF overall globalization index & $\begin{array}{l}\text { This is a composite index of globalization which } \\
\text { consists of equal weights }(33.3 \%) \text { of the three } \\
\text { dimensions of globalization-economic, social } \\
\text { and political globalization. }\end{array}$ & SEI & $+/-$ \\
\hline De facto overall globalization & De facto KOF overall globalization index & $\begin{array}{l}\text { It relates to information on the various de facto } \\
\text { measures of the three dimensions of } \\
\text { globalization. }\end{array}$ & SEI & $+/-$ \\
\hline De jure overall globalization & De jure KOF overall globalization index & $\begin{array}{l}\text { This index aggregates information on the } \\
\text { various de jure measures of the three dimensions } \\
\text { of globalization. }\end{array}$ & SEI & $+/-$ \\
\hline Economic globalization (overall) & KOF economic globalization index & $\begin{array}{l}\text { It consists of information on the de facto and de } \\
\text { jure aspects of trade and financial globalization. }\end{array}$ & SEI & $+/-$ \\
\hline De facto economic globalization & De facto KOF economic globalization index & $\begin{array}{l}\text { An index based on information relating to } \\
\text { international trade and capital flows. }\end{array}$ & SEI & $+/-$ \\
\hline De jure economic globalization & De jure KOF economic globalization index & $\begin{array}{l}\text { This is an index constructed from information } \\
\text { regarding policies and regulations guiding } \\
\text { international trade and capital flows as well as } \\
\text { cross-border investments. }\end{array}$ & SEI & $+/-$ \\
\hline Social globalization (overall) & KOF social globalization index & $\begin{array}{l}\text { This index is based on de facto and de jure } \\
\text { measures of interpersonal, informational and } \\
\text { cultural globalization. }\end{array}$ & SEI & $+/-$ \\
\hline De facto social globalization & De facto KOF social globalization index & $\begin{array}{l}\text { It is built on information regarding international } \\
\text { voice traffic, international migration, }\end{array}$ & SEI & $+/-$ \\
\hline
\end{tabular}


De jure social globalization

Political globalization (overall)

De facto political globalization

De jure political globalization
De jure KOF social globalization index

KOF political globalization index

De facto KOF political globalization index

De jure KOF political globalization index

international transfers, internet bandwidth subscription, international patents, high technology exports, trade in cultural goods and personal services and number of trademark applications by non-residents of a country.

This index contains information relating to number of telephone subscriptions, international

travel restrictions (freedom to visit), number of international airports, access to internet, access to television, freedom of press, human capital, gender parity and civil liberties.

It consists of de facto and de jure measures of political globalization.

It is formed on the basis of number of involvements in United Nations peacekeeping missions and number of embassies and international non-governmental agencies situated in a country.

It is based on the amount of participation in multilateral agreements and international organizations as well as a treaty partner diversity measure.

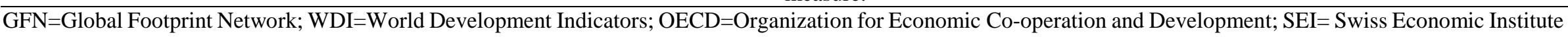


Table A.3

Descriptive statistics

\begin{tabular}{lcccc}
\hline Variable & Mean & $\begin{array}{c}\text { Standard } \\
\text { Deviation }\end{array}$ & Minimum & Maximum \\
\hline Environmental degradation & 5.293 & 2.078 & 0.061 & 10.482 \\
Population & $9.30 \times 10^{7}$ & $2.36 \times 10^{8}$ & $3,135,083$ & $1.37 \times 10^{9}$ \\
Affluence & $32,731.07$ & $20,203.55$ & 786.130 & $91,565.73$ \\
Technology & 1.594 & 0.832 & 0.177 & 4.078 \\
Overall globalization (overall) & 77.379 & 10.067 & 39.182 & 91.168 \\
De facto overall globalization & 74.049 & 11.082 & 41.715 & 92.141 \\
De jure overall globalization & 80.719 & 10.354 & 36.648 & 93.741 \\
Economic globalization (overall) & 68.220 & 15.024 & 27.806 & 95.431 \\
De facto economic globalization & 59.480 & 18.861 & 20.638 & 98.627 \\
De jure economic globalization & 76.965 & 14.045 & 32.922 & 94.867 \\
Social globalization (overall) & 75.472 & 12.824 & 17.943 & 92.118 \\
De facto social globalization & 74.580 & 14.071 & 17.864 & 97.777 \\
De jure social globalization & 76.392 & 12.584 & 18.022 & 91.603 \\
Political globalization (overall) & 88.431 & 8.375 & 57.795 & 98.711 \\
De facto political globalization & 88.088 & 7.297 & 55.796 & 98.345 \\
De jure political globalization & 88.775 & 11.269 & 45.552 & 100 \\
\hline
\end{tabular}


Table A. 4

CD test results for variables (in logarithm)

\begin{tabular}{lcc}
\hline Variable & CD test & $p$-value \\
\hline Environmental degradation & $13.46^{* * *}$ & 0.000 \\
Population & $35.68 * * *$ & 0.000 \\
Affluence & $83.39 * * *$ & 0.000 \\
Technology & $31.94 * * *$ & 0.000 \\
Overall globalization (overall) & $90.19 * * *$ & 0.000 \\
De facto overall globalization & $85.39 * * *$ & 0.000 \\
De jure overall globalization & $84.25 * * *$ & 0.000 \\
Economic globalization (overall) & $80.79 * * *$ & 0.000 \\
De facto economic globalization & $80.83 * * *$ & 0.000 \\
De jure economic globalization & $33.63 * * *$ & 0.000 \\
Social globalization (overall) & $92.63 * * *$ & 0.000 \\
De facto social globalization & $86.91 * * *$ & 0.000 \\
De jure social globalization & $89.69 * * *$ & 0.000 \\
Political globalization (overall) & $76.97 * * *$ & 0.000 \\
De facto political globalization & $25.50 * * *$ & 0.000 \\
De jure political globalization & $85.48 * * *$ & 0.000 \\
\hline
\end{tabular}

Note: $* * *$ indicates $\mathrm{p}$-value does not exceed 0.01 .

Table A.5

CD test results for models

\begin{tabular}{|c|c|c|c|c|c|c|}
\hline \multirow[t]{2}{*}{ Model } & \multicolumn{2}{|c|}{ Overall } & \multicolumn{2}{|c|}{ De facto } & \multicolumn{2}{|c|}{ De jure } \\
\hline & No trend & With trend & No trend & With trend & No trend & With trend \\
\hline \multirow[t]{2}{*}{$\mathrm{ED}_{\mathrm{it}}=\mathrm{f}\left(\ln \mathrm{P}_{\mathrm{it}}, \ln \mathrm{A}_{\mathrm{it}}, \ln \mathrm{T}_{\mathrm{it}}, \ln \mathrm{OG}_{\mathrm{it}}\right)$} & $14.11 * * *$ & $12.76 * * *$ & $13.06 * * *$ & $9.643 * * *$ & $15.94 * * *$ & $11.54 * * *$ \\
\hline & $(0.000)$ & $(0.000)$ & $(0.000)$ & $(0.000)$ & $(0.000)$ & $(0.000)$ \\
\hline \multirow[t]{2}{*}{$\mathrm{ED}_{\mathrm{it}}=\mathrm{f}\left(\ln \mathrm{P}_{\mathrm{it}}, \ln \mathrm{A}_{\mathrm{it}}, \ln \mathrm{T}_{\mathrm{it}}, \ln \mathrm{EG}_{\mathrm{it}}\right)$} & $14.29 * * *$ & $12.44 * * *$ & $15.50 * * *$ & $10.72 * * *$ & $11.90 * * *$ & $9.60 * * *$ \\
\hline & $(0.000)$ & $(0.000)$ & $(0.000)$ & $(0.000)$ & $(0.000)$ & $(0.000)$ \\
\hline \multirow[t]{2}{*}{$\mathrm{ED}_{\mathrm{it}}=\mathrm{f}\left(\ln \mathrm{P}_{\mathrm{it}}, \ln \mathrm{A}_{\mathrm{it}}, \ln \mathrm{T}_{\mathrm{it}}, \ln \mathrm{SG}_{\mathrm{it}}\right)$} & $17.24 * * *$ & $14.15 * * *$ & $17.62 * * *$ & $14.88 * * *$ & $18.64 * * *$ & $12.90 * * *$ \\
\hline & $(0.000)$ & $(0.000)$ & $(0.000)$ & $(0.000)$ & $(0.000)$ & $(0.000)$ \\
\hline \multirow[t]{2}{*}{$\mathrm{ED}_{\mathrm{it}}=\mathrm{f}\left(\ln \mathrm{P}_{\mathrm{it}}, \ln \mathrm{A}_{\mathrm{it}}, \ln \mathrm{T}_{\mathrm{it}}, \ln \mathrm{PG}_{\mathrm{it}}\right)$} & $19.83 * * *$ & $11.58 * * *$ & $13.29 * * *$ & $8.365^{* * *}$ & $18.43 * * *$ & $11.66 * * *$ \\
\hline & $(0.000)$ & $(0.000)$ & $(0.000)$ & $(0.000)$ & $(0.000)$ & $(0.000)$ \\
\hline
\end{tabular}

Notes: Values in brackets are p-values and $* * *$ indicates $\mathrm{p}$-value does not exceed 0.01 . 
Table A.6

Panel unit root test results for variables (in logarithm)

\begin{tabular}{|c|c|c|c|c|}
\hline \multirow[t]{2}{*}{ Variable } & \multicolumn{2}{|c|}{ Level } & \multicolumn{2}{|c|}{ First difference } \\
\hline & No trend & With trend & No trend & With trend \\
\hline \multirow{2}{*}{ Environmental degradation } & 4.071 & 3.371 & $-7.759 * * *$ & $-5.671 * * *$ \\
\hline & $(1.000)$ & $(1.000)$ & $(0.000)$ & $(0.000)$ \\
\hline \multirow[t]{2}{*}{ Population } & $-1.500 *$ & 0.724 & $-7.046 * * *$ & $-5.392 * * *$ \\
\hline & $(0.067)$ & $(0.765)$ & $(0.000)$ & $(0.000)$ \\
\hline \multirow[t]{2}{*}{ Affluence } & 3.012 & 8.182 & $-5.833 * * *$ & $-6.781 * * *$ \\
\hline & $(0.999)$ & $(1.000)$ & $(0.000)$ & $(0.000)$ \\
\hline \multirow[t]{2}{*}{ Technology } & 3.571 & 5.555 & $-2.051 * *$ & $-1.923 * *$ \\
\hline & $(1.000)$ & $(1.000)$ & $(0.020)$ & $(0.027)$ \\
\hline \multirow[t]{2}{*}{ Overall globalization (overall) } & $-1.705 * *$ & -0.243 & $-3.655 * * *$ & $-2.206 * *$ \\
\hline & $(0.044)$ & $(0.404)$ & $(0.000)$ & $(0.014)$ \\
\hline \multirow[t]{2}{*}{ De facto overall globalization } & $-1.794 * *$ & -0.828 & $-4.664 * * *$ & $-1.468 *$ \\
\hline & $(0.036)$ & $(0.204)$ & $(0.000)$ & $(0.071)$ \\
\hline \multirow[t]{2}{*}{ De jure overall globalization } & $-3.789 * * *$ & -0.356 & $-3.781 * * *$ & $-2.206 * *$ \\
\hline & $(0.000)$ & $(0.361)$ & $(0.000)$ & $(0.014)$ \\
\hline \multirow[t]{2}{*}{ Economic globalization (overall) } & $-2.751 * * *$ & -0.553 & $-2.695 * * *$ & $-1.584 *$ \\
\hline & $(0.003)$ & $(0.290)$ & $(0.004)$ & $(0.057)$ \\
\hline \multirow[t]{2}{*}{ De facto economic globalization } & $-3.290 * * *$ & $-2.825 * * *$ & $-4.694 * * *$ & $-1.340 *$ \\
\hline & $(0.001)$ & $(0.002)$ & $(0.000)$ & $(0.090)$ \\
\hline \multirow[t]{2}{*}{ De jure economic globalization } & $-3.759 * * *$ & 2.186 & $-1.671 * *$ & $-1.468 *$ \\
\hline & $(0.000)$ & $(0.986)$ & $(0.047)$ & $(0.071)$ \\
\hline \multirow[t]{2}{*}{ Social globalization (overall) } & $-1.986 * *$ & -0.172 & $-2.779 * * *$ & $-2.043 * *$ \\
\hline & $(0.024)$ & $(0.432)$ & $(0.003)$ & $(0.021)$ \\
\hline \multirow[t]{2}{*}{ De facto social globalization } & $-2.784 * * *$ & -0.852 & $-3.253 * * *$ & $-4.303 * * *$ \\
\hline & $(0.003)$ & $(0.197)$ & $(0.001)$ & $(0.000)$ \\
\hline \multirow[t]{2}{*}{ De jure social globalization } & $-2.213 * *$ & -0.003 & $-4.627 * * *$ & $-2.428 * * *$ \\
\hline & $(0.013)$ & $(0.499)$ & $(0.000)$ & $(0.008)$ \\
\hline \multirow[t]{2}{*}{ Political globalization (overall) } & $-2.380 * * *$ & -0.611 & $-7.075 * * *$ & $-3.356 * * *$ \\
\hline & $(0.009)$ & $(0.271)$ & $(0.000)$ & $(0.000)$ \\
\hline \multirow[t]{2}{*}{ De facto political globalization } & -0.952 & 2.872 & $-2.991 * * *$ & $-1.807 * *$ \\
\hline & $(0.171)$ & $(0.998)$ & $(0.001)$ & $(0.035)$ \\
\hline \multirow[t]{2}{*}{ De jure political globalization } & $-4.610 * * *$ & $-2.781 * * *$ & $-7.410 * * *$ & $-4.866 * * *$ \\
\hline & $(0.000)$ & $(0.003)$ & $(0.000)$ & $(0.000)$ \\
\hline
\end{tabular}

Notes: Values in brackets are p-values and $* * *, * *$ and $*$ indicate $\mathrm{p}$-value does not exceed $0.01,0.05$ and 0.1 , respectively.

Table A.7

Slope homogeneity test results

\begin{tabular}{|c|c|c|c|c|c|c|}
\hline \multirow[t]{2}{*}{ Model } & \multicolumn{2}{|c|}{ Overall } & \multicolumn{2}{|c|}{ De facto } & \multicolumn{2}{|c|}{ De jure } \\
\hline & $\begin{array}{l}\text { Standard } \\
\text { delta }\end{array}$ & $\begin{array}{c}\text { Bias-adjusted } \\
\text { delta }\end{array}$ & $\begin{array}{c}\text { Standard } \\
\text { delta }\end{array}$ & $\begin{array}{c}\text { Bias-adjusted } \\
\text { delta }\end{array}$ & $\begin{array}{c}\text { Standard } \\
\text { delta }\end{array}$ & $\begin{array}{c}\text { Bias-adjusted } \\
\text { delta }\end{array}$ \\
\hline $\mathrm{ED}_{\mathrm{it}}=\mathrm{f}\left(\ln \mathrm{P}_{\mathrm{it}}, \ln \mathrm{A}_{\mathrm{it}}, \ln \mathrm{T}_{\mathrm{it}}, \ln \mathrm{OG}_{\mathrm{it}}\right)$ & $\begin{array}{c}22.179 * * * \\
(0.000)\end{array}$ & $\begin{array}{c}24.679 * * * \\
(0.000)\end{array}$ & $\begin{array}{c}20.960 * * * \\
(0.000)\end{array}$ & $\begin{array}{c}23.323 * * * \\
(0.000)\end{array}$ & $\begin{array}{c}22.565 * * * \\
(0.000)\end{array}$ & $\begin{array}{c}25.108 * * * \\
(0.000)\end{array}$ \\
\hline $\mathrm{ED}_{\mathrm{it}}=\mathrm{f}\left(\ln \mathrm{P}_{\mathrm{it}}, \ln \mathrm{A}_{\mathrm{it}}, \ln \mathrm{T}_{\mathrm{it}}, \operatorname{lnEG_{it}}\right)$ & $\begin{array}{c}22.340 * * * \\
(0.000)\end{array}$ & $\begin{array}{c}24.857 * * * \\
(0.000)\end{array}$ & $\begin{array}{c}22.242 * * * \\
(0.000)\end{array}$ & $\begin{array}{c}24.749 * * * \\
(0.000)\end{array}$ & $\begin{array}{c}22.265^{* * * *} \\
(0.000)\end{array}$ & $\begin{array}{c}24.774 * * * \\
(0.000)\end{array}$ \\
\hline $\mathrm{ED}_{\mathrm{it}}=\mathrm{f}\left(\ln \mathrm{P}_{\mathrm{it}}, \ln \mathrm{A}_{\mathrm{it}}, \ln \mathrm{T}_{\mathrm{it}}, \ln \mathrm{SG}_{\mathrm{it}}\right)$ & $\begin{array}{c}23.151 * * * \\
(0.000)\end{array}$ & $\begin{array}{c}25.761 * * * \\
(0.000)\end{array}$ & $\begin{array}{c}22.783 * * * \\
(0.000)\end{array}$ & $\begin{array}{c}25.350 * * * \\
(0.000)\end{array}$ & $\begin{array}{c}22.787 * * * \\
(0.000)\end{array}$ & $\begin{array}{c}25.355 * * * \\
(0.000)\end{array}$ \\
\hline $\mathrm{ED}_{\mathrm{it}}=\mathrm{f}\left(\ln \mathrm{P}_{\mathrm{it}}, \ln \mathrm{A}_{\mathrm{it}}, \ln \mathrm{T}_{\mathrm{it}}, \ln \mathrm{PG}_{\mathrm{it}}\right)$ & $\begin{array}{c}21.494^{* * * *} \\
(0.000)\end{array}$ & $\begin{array}{c}23.917 * * * \\
(0.000)\end{array}$ & $\begin{array}{c}20.761 * * * \\
(0.000)\end{array}$ & $\begin{array}{c}23.100 * * * \\
(0.000)\end{array}$ & $\begin{array}{c}22.756 * * * \\
(0.000)\end{array}$ & $\begin{array}{c}25.321 * * * \\
(0.000)\end{array}$ \\
\hline
\end{tabular}

Notes: Values in brackets are p-values and $* * *$ indicates $\mathrm{p}$-value does not exceed 0.01 . 